\title{
Private Sector Deleveraging and Growth Following Busts
}


Private Sector Deleveraging and Growth Following Busts

Sally Chen, Minsuk Kim, Marijn Otte, Kevin Wiseman, Aleksandra Zdzienicka 


\title{
IMF Working Paper
}

\section{Private Sector Deleveraging and Growth Following Busts \\ Prepared by Sally Chen, Minsuk Kim, Marijn Otte, Kevin Wiseman, and Aleksandra Zdzienicka}

Authorized for distribution by Vikram Haksar

February 2015

\begin{abstract}
This Working Paper should not be reported as representing the views of the IMF. The views expressed in this Working Paper are those of the author(s) and do not necessarily represent those of the IMF or IMF policy. Working Papers describe research in progress by the author(s) and are published to elicit comments and to further debate.
\end{abstract}

\begin{abstract}
Balance sheet recessions have been a drag on activity after the Global Financial Crisis, underscoring the important role of balance sheet adjustment for resuming sustained growth. In this paper we examine private sector deleveraging experiences across 36 advanced and emerging economies countries since 1960. We consider the common features and divergent experiences of deleveraging episodes across countries, and analyze empirically the impact of different aspects of deleveraging during the bust phase of leverage cycles on subsequent medium-term growth. The results suggest that larger and quicker unwinding of non-financial sector debt overhangs is associated with sizable medium-term output gains, and that policies should focus on facilitating up-front balance sheet adjustment.
\end{abstract}

JEL Classification Numbers: E21, E51, G01, G33,C23

Keywords: deleveraging, leverage cycles, financial cycles, growth

Author’s E-Mail Address: schen@imf.org; mkim@imf.org; motte@imf.org; kwiseman@imf.org; azdzienicka@imf.org

\footnotetext{
*The authors are grateful to Vikram Haksar for his intellectual guidance and support. This paper benefited greatly from disucssions with Tamim Bayoumi, Stijn Claessens, Andrew Tiffin, Silvia Sgherri, Grace Bin Li, Fabian Bornhorst, Damiano Sandri and comments from Craig Beaumont, Helge Berger, Ruchir Agarwal, Alvaro Piris Chavarri as well as other participants in an IMF seminar.
} 


\section{INTRODUCTION}

The recent financial crises in advanced economies and their subsequent sluggish recoveries have focused attention on the implications of high levels of leverage and slow balance sheet adjustments. Although many aspects of policy responses have been swift and large - substantial increases in key central bank balance sheets, large government spending to offset the decline in private demand, sizable bank recapitalization to preserve some level of credit supply, to name a few - growth recoveries have been sluggish. This reflects, in part, the tremendous macroeconomic costs of the disorderly unwinding of large private debt expansion during the bubble years. Contrary to normal recessions, balance sheet recessions are more damaging and typically require deleveraging to allow debt overhang to be reabsorbed into the economy. To the extent that stressed European economies have yet to delever sufficiently, debt overhangs may be holding back their recoveries. Against this backdrop, still-rising debt levels in emerging markets and select advanced economies suggest that were shocks to arise, recovery could be constrained by balance sheet concerns in many parts of the world.

History suggests that deleveraging following financial crises is typical and tends to be sizable. Tang and Upper (2010) found, in countries that suffered systemic banking crises, private sector debt-to-GDP ratios fall on average by 38 percentage points before returning to levels seen before the credit boom. McKinsey (2012), examining deleveraging episodes (including both private and public debt) across large emerging and advanced economies, found deleveraging lasts on average seven years and is associated with a decline in debt-to-GDP ratio of 25 percentage points. In a similar vein, IMF (April 2012) found that household deleveraging takes roughly seven years following busts associated with a large increase in household debt, with a decline in debt-to-income ratio of roughly 23 percentage points.

The historical experience is clear-deleveraging processes run their course eventually. But to the extent that demand is held back by debt overhang currently, policy responses to deal with this specific aspect have been more constrained, with policies in advanced economies to date focusing on shoring up aggregate demand and boosting credit supply. This in part reflects that household debt increases, a common feature in many advanced economies in the current leverage cycle, pose a particularly complex challenge from a policy perspective. Households are much smaller, scattered, less amenable to centralized solutions, and often politically sensitive as the major asset in such cases are homes. Moreover, bankruptcy and debt default proceedings across countries are idiosyncratic and complex. In the U.S. where the non-recourse mortgage framework and active government policies enabled larger household debt reductions, the output recovery is expected to be stronger than Europe, where it has proven harder to achieve substantial deleveraging.

A logical question then is to what extent has unfinished balance sheet adjustment held back recovery? Given the expected - and necessary - balance sheet adjustments following financial crises, does the modality of deleveraging - its magnitude and speed - matter for growth prospects going forward?

Prior research has mostly explored the impact of levels of debt and leverage on growth, but detailed assessments on the impact of changes in leverage (deleveraging) is limited. Of those 
that address the impact of deleveraging on growth, most have focused on public sector balance sheet adjustments. Those that do address the issue of private sector deleveraging tend to be limited to the effect of deleveraging size on growth and focused on economies with rich, detailed data, such as the U.S. and other advanced economies. This paper aims to broaden our understanding of the dynamics of deleveraging on growth by analyzing a cross-country sample of episodes over the last 50 years and going beyond the experiences of advanced economies and the impact of deleveraging size. Specifically, this paper examines the modalities of deleveraging across both advanced and emerging economies and assesses the impact on growth from the size of total deleveraging, as well as the duration of these episodes and the intensity of deleveraging efforts over these intervening periods.

The paper is structured as follows: in section II, we review the literature on leverage, summarizing findings that connect leverage ratios and growth. In section III, we offer a close look at deleveraging episodes for a wide range of countries from 1960. We find a secular increase in leverage - defined as nominal debt to nominal income - across both advanced and emerging market economies, suggesting financial deepening and income growth may have played a role. We also find that peaks in these leverage cycles occur on average every 19 years; deleveraging experiences are not uncommon and tend to last approximately four to five years on average. In section IV, we offer a novel approach to assess the impact of deleveraging on medium-term growth. Here, given the complexities of deleveraging experiences - changes in nominal debt levels, the impact of changing interest rates, growth and inflation, and not the least of all, valuation effects - we focus on changes in leverage ratios and more specifically, the intensity and duration during which private borrowers adjust these ratios and the attendant impact on future output. We find that larger, more up-front deleveraging does boost mediumterm growth, other things equal. Lastly, section V concludes.

\section{LITERATURE REVIEW}

Traditionally, economists have focused on private debt only to the extent that it affects household net worth and correspondingly, consumption (Benito and Zampolli, 2007; Dynan and Kohn, 2007). Recent work has shown that the accumulation of debt and subsequent retrenchment may have played a role in lowering demand in the U.S., Europe, and elsewhere (Eggertson and Krugman, 2010; Philippon and Midrigan, 2011). In particular, Mian, Rao and Sufi (2011) provided strong empirical evidence that household debt accumulation in the mid2000s and subsequent busts contributed to the ensuing decline in consumption and economic crises. Along the same line, Meltzer (2010) found that households with negative equity - debt overhang - spent 30 percent less on home improvements and maintenances than those without debt overhang. Taken together, these recent works offer a theoretical justification for analyzing the dynamics of private sector leverage and their impact on economic growth.

There are several themes common in the current literature on debt and growth. First, there is a distinct credit cycle, characterized by changes in credit aggregates and asset values. In the post WWII era, these credit cycles have been increasingly characterized by rising credit and complex forms of leverage (Schularick and Taylor, 2010). Moreover, these credit cycles are driven by leverage, which determines asset values and affects economic cycles (Geanakoplos, 2010). Here, the literature on capital structure and its economic consequences has evolved over the years. Modigliani and Miller (1958) set the tone for a period, stressing that with perfect capital 
markets, capital structure does not affect a firm's cost of capital and hence investment decisions. But since then a large literature has developed in finance, focusing on a wide range of frictions that insert wedges into the cost of finance depending on capital structure, thus affecting aggregate outcomes (Tirole, 2011).

Second, credit matters for growth. Intuitively one might expect a positive correlation between debt levels and output as debt allows for consumption and investment smoothing over uncertain income, and financial deepening and rising debt go hand in hand with output. In reality, roughly one in five growth recoveries occur in the absence of credit growth - the so called "creditless recoveries", but such recoveries tend to be shallow (Abiad, Dell'Ariccia, and Li, 2011). Specifically, negative real credit growth in the first three years following a recession is more likely if the downturn is preceded by credit booms or coincided with a banking crisis. Weak credit growth may reflect, in part, banks' increased risk aversion and more cautious lending activities. The policy prescription related to supply constraint as noted here is clear - boost bank capital and restore credit supply to avert a credit crunch, as demonstrated clearly in Laevan and Valencia (2011).

That said, the demand side of the equation also matters; the ability to borrow is not indefinite. Debt levels above a particular threshold may be associated with compromised medium-term growth prospects (Cecchetti et al., 2011; Kumar and Woo, 2010; Baum et al., 2013; Reinhart and Rogoff, 2010). The consensus here, however, is less clear. Existing literature generally suggest that high debt levels are negatively associated with growth performance, but the threshold at which debt levels begin to matter differs across studies. For OECD countries, the threshold for government debt is around 85 percent of GDP, corporate debt, 90 percent of GDP and households, 85 percent (Cecchetti et al., 2011). In another study, the government debt threshold is slightly higher across a wider range of countries, at around 90 percent (Reinhart and Rogoff, 2010). More generally, increases in debt levels - beyond a particular threshold - are often found to detract from future growth. Estimates range from a reduction in average annual growth rate of 2 to around 20 basis points for every 10 percentage point increase in the private sector debt-to-GDP ratio (Cecchetti et al., 2011; Randveer et al., 2011; Takats and Upper, 2013; Bech et al., 2012).

Third, movements in aggregate debt and asset ratios affect financial stability. Sharp increases in credit provision are seen as a key predictor of financial or banking crises (Friedman, 1986, Gourinchas and Obstfeld, 2012). In general, credit growth tends to be elevated and natural interest rates depressed in the run-up to financial crises, with credit growth seen as the single best predictor of financial instability (Jorda et al., 2010).

Along the same line, there is some evidence that the trajectory of debt may be more important than the level of debt, that is, countries with high, but declining levels of debt have historically grown just as fast as their peers (Pescatori et al, 2014). That said, deleveraging comes with a tradeoff. The process of deleveraging from high debt levels is generally seen as costly. Historic experiences suggest that deleveraging episodes are associated with contracting outputs during the first several years (McKinsey, 2012). Financial crises, in particular, tend to be followed by a prolonged period of deleveraging in the corporate sector (Tang and Upper, 2010). Recent analysis of U.S. household balance sheet adjustment suggests that the magnitude of 
deleveraging is correlated with economic performance - higher deleveraging is associated with sharper swings in housing markets, larger increases in mortgage delinquencies and worse labor market performance (Albuquerque et al., 2014). Moreover, private sector debt deleveraging may be more detrimental to growth than public sector debt (IMF 2013).

That said, detailed empirical analysis on the nature and composition of private debt dynamics is scarce, in part because changes in private balance sheets are often microeconomic in nature. Public sector debt typically involves a single, well-understood borrower and good data on the debt portfolio by maturity and interest rates, primary balances, and debt forgiveness. While the burden of public debt deleveraging falls on fiscal consolidation, private sector deleveraging operates through diverse channels and agents- consumption and investment, households and corporates. Moreover, factors that underlie changes in private leverage - the composition of borrowers, evolution of risk premia and loan terms, write-offs, refinancing, and new borrowing - can have varying effects on growth. It is then perhaps unsurprising that given such complexities, the literature on private sector deleveraging has much scope for development. Our analysis is the first effort to our knowledge to relate changes in the level of private leverage after a peak to subsequent medium-term growth. More specifically, it contributes to the analytical discussion on two fronts: first, we find that the size of deleveraging, all else equal, affects subsequent growth. Second, the modality of deleveraging matters - sizable subsequent growth is best achieved via more intense, upfront deleveraging where the length of deleveraging is limited.

\section{A Closer Look at Private Sector Deleveraging -- Stylized Facts}

Sustained increases in the leverage of households and firms have magnified the role of credit cycles in macroeconomic developments, as noted by Kiyotaki and Moore (1997) and more recently, Claessens et al. (2011). Taking periods of deleveraging episode by episode, this section looks at when and how these events occur and the consequences on the economy more generally.

In identifying relevant variables, we rely on nominal debt-to-nominal GDP ratios to measure private-sector leverage. Specifically, we measure leverage from an affordability perspective, using income as a proxy for the underlying pool of resources available to service the debt. For the numerator, the rationale for using total debt stock is twofold: Debt service figures do not accurately reflect the associated long-term obligations such as the number of years of the payment commitment or the term structure of interest rates that could improve affordability in the short term but raise payments later. Second, debt contracts are written in nominal terms, and the ability to repay is therefore based on nominal income; here, we rely on GDP - given limited sectoral data - as a proxy. This use of debt stock-to-income ratios is in line with credit rating agencies' methodology of comparing debt burdens across different countries and states (Boston Fed, 2013). That said, we recognize that debt-to-income is not a comprehensive measure of balance sheet stress. Assessing the total stock of debt relative to the composition of assets - the extent of liquid holdings, for example - and equity buffers could also offer useful insights into debt sustainability. 


\section{A. Broad Trends in Private Sector Debt}

Using BIS data on household and non-financial corporate gross debt, we constructed a sample of 36 countries with data ranging from 1960 to 2013. Private sector debt as a fraction of GDP has been on the rise across countries since as far back as the 1960s, growing from an average of 62 percent of GDP 1960 to 157 percent in 2012 across the countries in our sample (chart below). While leverage growth has been steady for advanced economies and emerging markets, it has occurred in different ways.

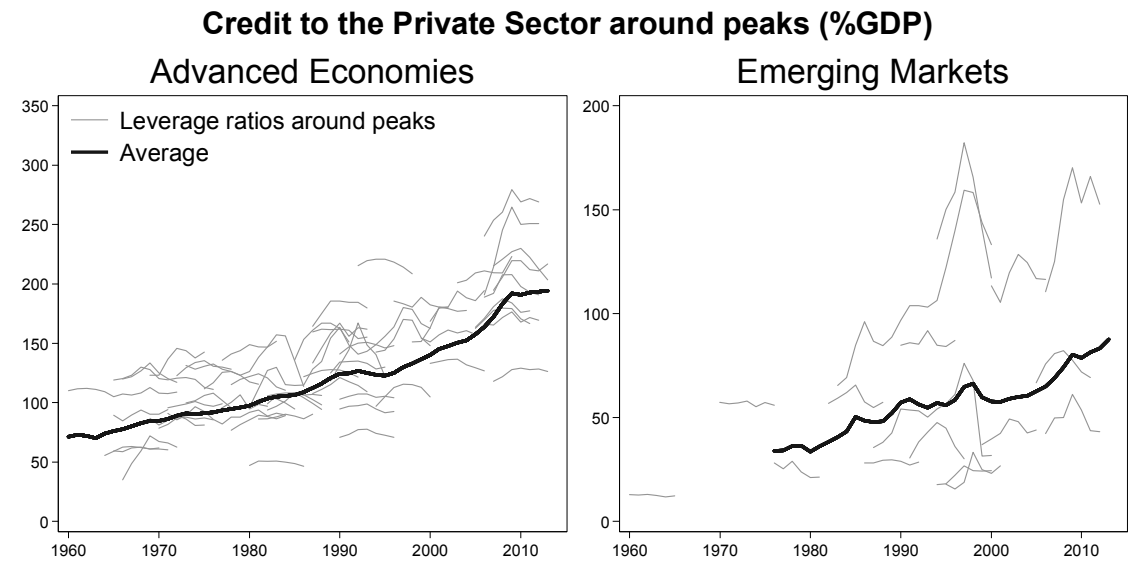

Leverage ratios in advanced economies, with greater financial depth, grew steadily from 71 percent to 193 percent of GDP between 1960 and 2013. ${ }^{1}$ Advanced economies saw strong nominal debt growth offset by high output growth in the 1960s and high inflation in the 1970s. Inflation moderated by the 1990s, and leverage saw its longest period of sustained growth from the 90s through the crisis (right-hand side text chart below).

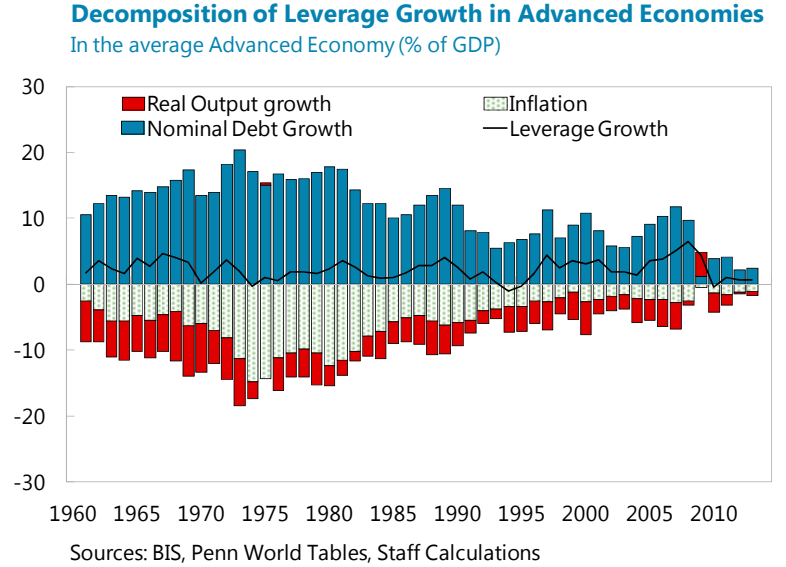

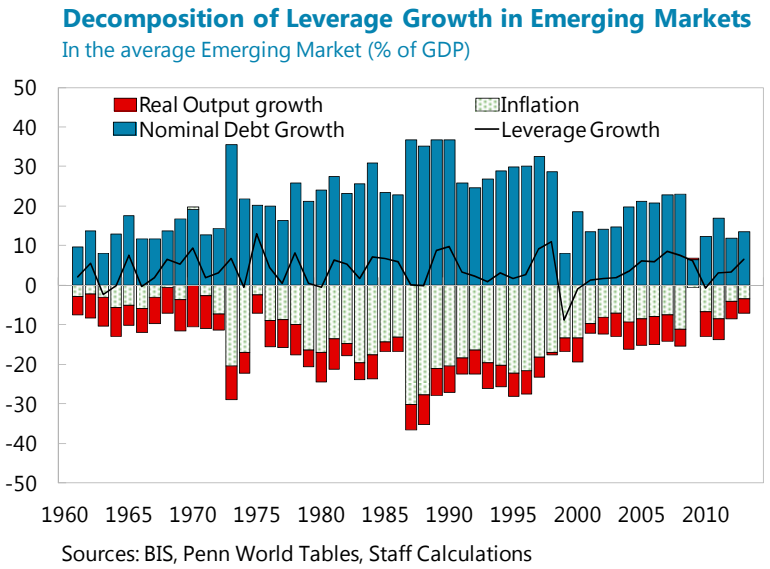

\footnotetext{
${ }^{2}$ Advanced economies: Australia, Austria, Belgium, Canada, Czech Republic, Denmark, Finland, France, Germany, Greece, Hong Kong, Ireland, Italy, Japan, Netherlands, Norway, Portugal, Singapore, South Korea, Spain, Sweden, Switzerland, United Kingdom, United States. Emerging economies: China, Hungary, India, Indonesia, Malaysia, Mexico, Poland, Russia, Saudi Arabia, South Africa, Thailand, Turkey.
} 
Emerging markets, starting from a lower base, also increased their leverage, growing from 13 percent to 83 percent in the same period. Average leverage growth was more volatile than in AEs with greater leverage growth peaks and deeper troughs (left-hand side text chart previous page). Strong real output growth tempered leverage growth throughout the sample. High inflation in the late 1980s and 1990s coincided with rising nominal GDP and reduced leverage; but this decline in leverage ratio was largely offset by increases in nominal interest rates. The Asian Financial Crisis is the largest aggregate event for emerging markets in the series, while the Global Financial Crisis and its growth consequences are particularly noteworthy for advanced economies.

Along with financial sector deepening there has been a change in the composition of gross debt, particularly in emerging markets. In spite of dramatic growth in corporate debt in the past few decades, household debt has grown even faster, rising from 15 percent of total debt in 1989 to 34 percent in 2012 and rapidly approaching advanced market levels of 40 percent and higher. The growth of household debt as a share of total private sector debt is consistent with higher levels of economic development. We find in our sample that it rises with income per capita, converging to similar levels as corporate debt once income approaches US\$50,000 on a GDPper-capita basis (text charts). The rising share of household debt with income levels likely reflects higher levels of financial development which increase the ease of borrowing for households, though this is not our focus.
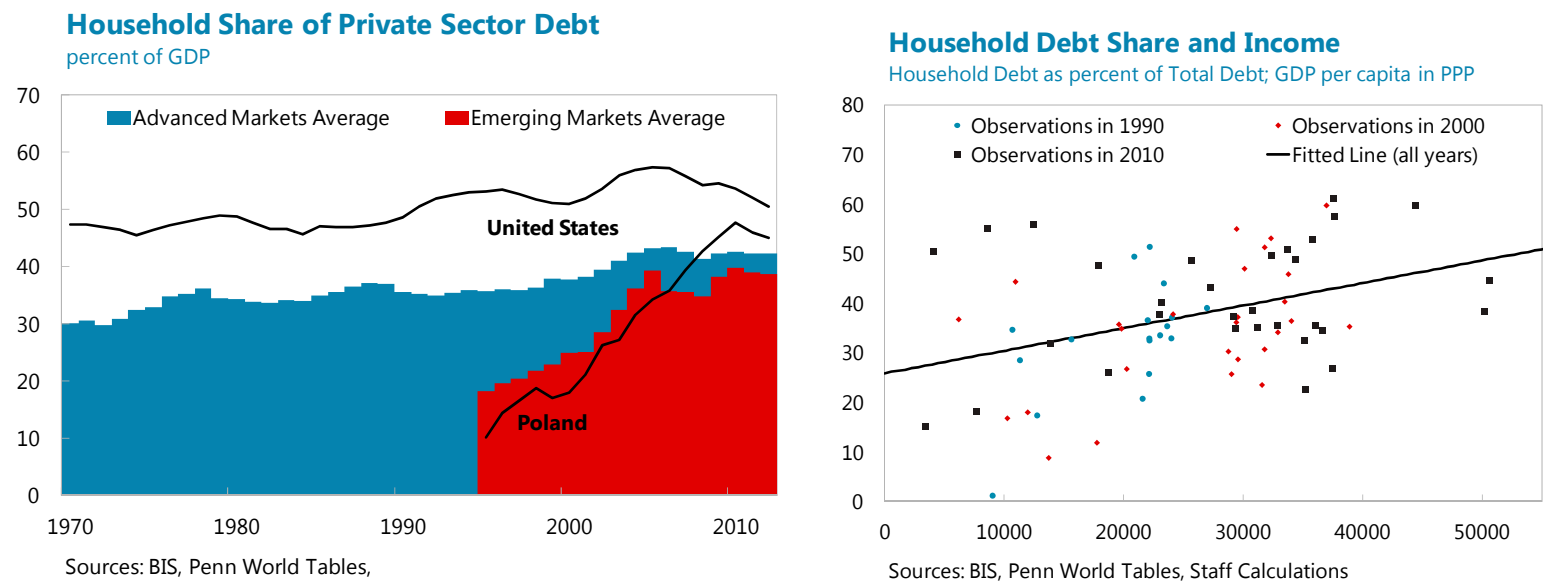

\section{B. Deleveraging Episodes}

To more closely examine the relationship between deleveraging and subsequent growth, we identify episodes of deleveraging across private sectors - both in aggregate as well as looking at households and nonfinancial corporate separately. In the process, we consider a number of features of these episodes, including the total size of deleveraging, the length of time spent deleveraging and the intensity of deleveraging - size of deleveraging per annum over the deleveraging period - and the effect of these features on growth outcomes ${ }^{2}$.

\footnotetext{
${ }^{2}$ The number of household deleveraging episodes - after stripping out those affiliated with the GFC - was too few for meaningful regression results.
} 
We identify deleveraging episodes with the dating algorithm introduced by Harding and Pagan (2002) to locate turning points in private debt-to-GDP ratios (Appendix I, Tables 1, 2, 3, and 4). There is not yet a well-established approach to financial cycle dating, but this algorithm is a simple, well-defined approach that is robust to the inclusion of new data. Using this turning point methodology, we searched for maxima (identified as "peaks") and minima ("troughs") over a given period. ${ }^{3}$ The difference between the local peak and trough is the total amount of deleveraging associated with a deleveraging episode (text chart). In a similar vein, the number

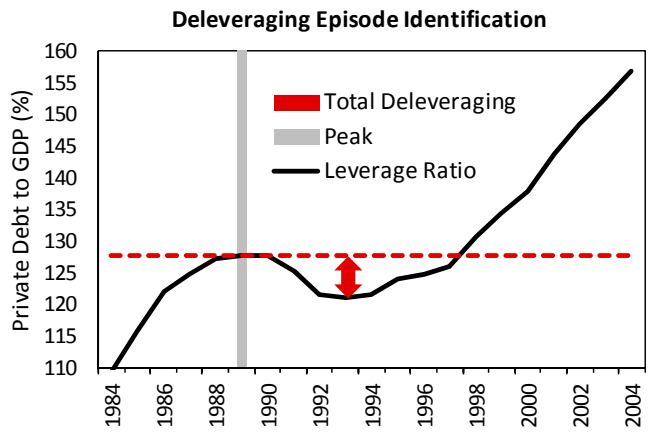
of years that span the interim between peak and trough is the duration of the episode.

Our exercise identified 83 deleveraging episodes, 63 among advanced economies (AEs) and 20 among emerging economies (EMs), with the smaller number for EMs explained by fewer countries and shorter series in the data. ${ }^{4}$

Deleveraging episodes occur less frequently than recessions, about once every 19 years on average with AEs and EMs seeing similar frequencies. Within these groups, episodes occurred for countries at every level of financial depth. Episodes were widely distributed across time as well. Deleveraging episodes are largely idiosyncratic through the mid-nineties but then become somewhat more synchronized, with some clustering around the Asian Financial Crisis, a lull in the mid 2000s, and then wide-spread

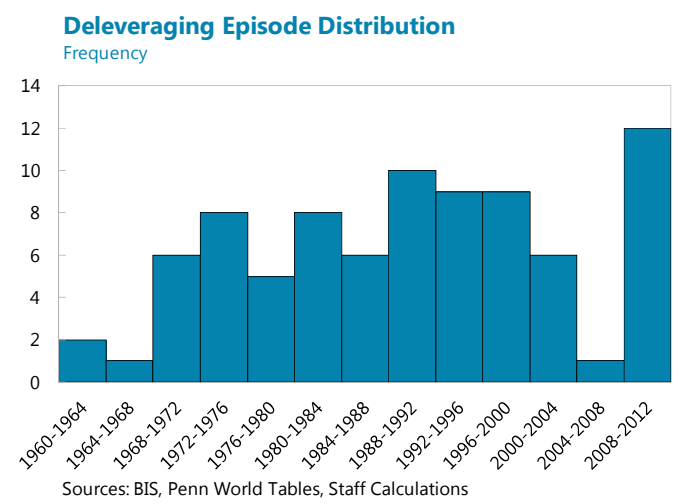
deleveraging with the highest frequency during the Global Financial Crisis (text chart).

\section{Length and Depth of Deleveraging Episodes}

Deleveraging experiences varied widely across economies and time periods, with some countries re-levering swiftly after a deep retrenchment, some experiencing only minor corrections, and others experiencing protracted periods of slow reductions in debt-to-GDP. Some events can even herald a period of secular decline in debt-to-GDP,

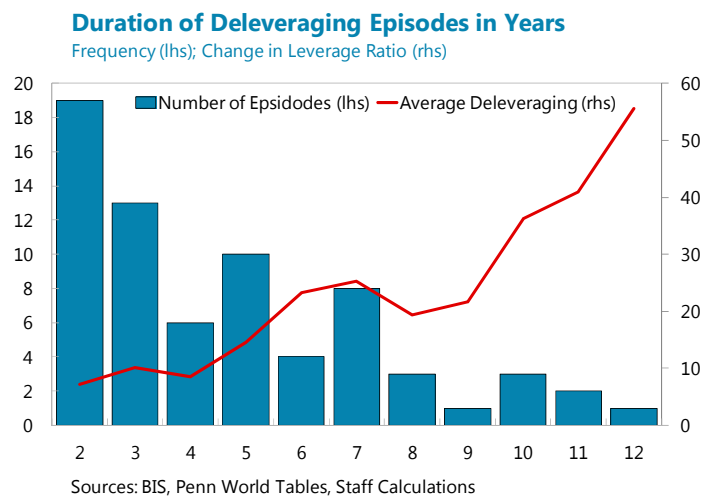

\footnotetext{
${ }^{3}$ The window is defined as two years, and a complete cycle is at least five years.

${ }^{4}$ Emerging markets represent 26 percent of annual observations on leverage and 24 percent of identified episodes, suggesting similar frequencies across levels of development.
} 
as Japan (1995) and Germany (2003) appear to have transitioned to a period of sustained reductions in leverage. On average, deleveraging episodes last roughly 5 years, ${ }^{5}$ with average debt-to-GDP levels falling by about 15 percentage points over this period. There is a wide range in the sample - some of the sharpest balance sheet adjustments took place within two or three years and some of the longest deleveraging spells were just as vigorous. That said, in general, the total size of adjustment increases with the amount of time spent deleveraging (text chart and table below).

\begin{tabular}{|c|c|c|c|c|}
\hline & Average & $\begin{array}{l}\text { Standard } \\
\text { Deviation }\end{array}$ & AEs & EMs \\
\hline Peak Leverage Ratio (\% of GDP) & 115.2 & 47.2 & 128.4 & 73.2 \\
\hline Deleveraging duration (years) & 4.7 & 2.7 & 4.6 & 4.8 \\
\hline \multicolumn{5}{|c|}{ Change in Leverage Ratio (annual avg; ppts) } \\
\hline Pre-deleveraging growth rate & 4.9 & 4.3 & 3.9 & 8.1 \\
\hline Peak to trough & -3.6 & 3.5 & -2.7 & -6.6 \\
\hline Post-trough & 4.2 & 3.1 & 3.5 & 6.4 \\
\hline \multicolumn{5}{|c|}{ Real GDP Growth (annual avg; \%YoY) } \\
\hline Pre-deleveraging & 4.1 & 3.0 & 3.8 & 5.3 \\
\hline Peak to trough & 3.8 & 2.7 & 3.3 & 5.5 \\
\hline Post-trough & 3.7 & 2.3 & 3.3 & 5.3 \\
\hline
\end{tabular}

1/ Based on available observations; pre-deleveraging and post-trough growth rates are 5 year averages.

\section{How Countries Delever}

To assess the mechanisms of deleveraging, we decompose the change in the private sector debtto-GDP ratio into real growth, inflation, and nominal debt stock changes ${ }^{6}$ during the

deleveraging episode. In general, deleveraging tends to be triggered by a combination of growth downturns - particularly when a slowdown has been in train for some time - and extended, large increases in debt levels. To put it differently, leverage ratios typically peaked when income and, correspondingly, the capacity to service debt, have deteriorated sizably. Subsequent deleveraging can be seen as a response to an unsustainable debt overhang.

Countries in the Asian Financial Crisis stand out as having had the most sizable absolute reduction in leverage in our sample with a particularly large contribution coming from positive output growth (chart above). Indeed, they had not moved very far from peak debt-to-GDP ratios after four years, suggesting that increases in growth enabled speedier releveraging. Nordic countries in the late 1980s and early 1990s delevered on the back of a relatively high rate of inflation-perhaps reflecting currency depreciation in a context where most debt was domestic though they also did not see a sizable net releveraging. By contrast, countries experiencing

5 Data on duration cover only episodes for which we can identify a trough thus excludes those with ongoing declines.

${ }^{6}$ Ideally, debt stock changes should be decomposed into retiring loans, new borrowing, and any debt relief or renegotiation. Detailed data for the vast majority of our sample were unfortunately not available. 
deleveraging episodes in the GFC period have seen far smaller movements in debt ratios and its components.

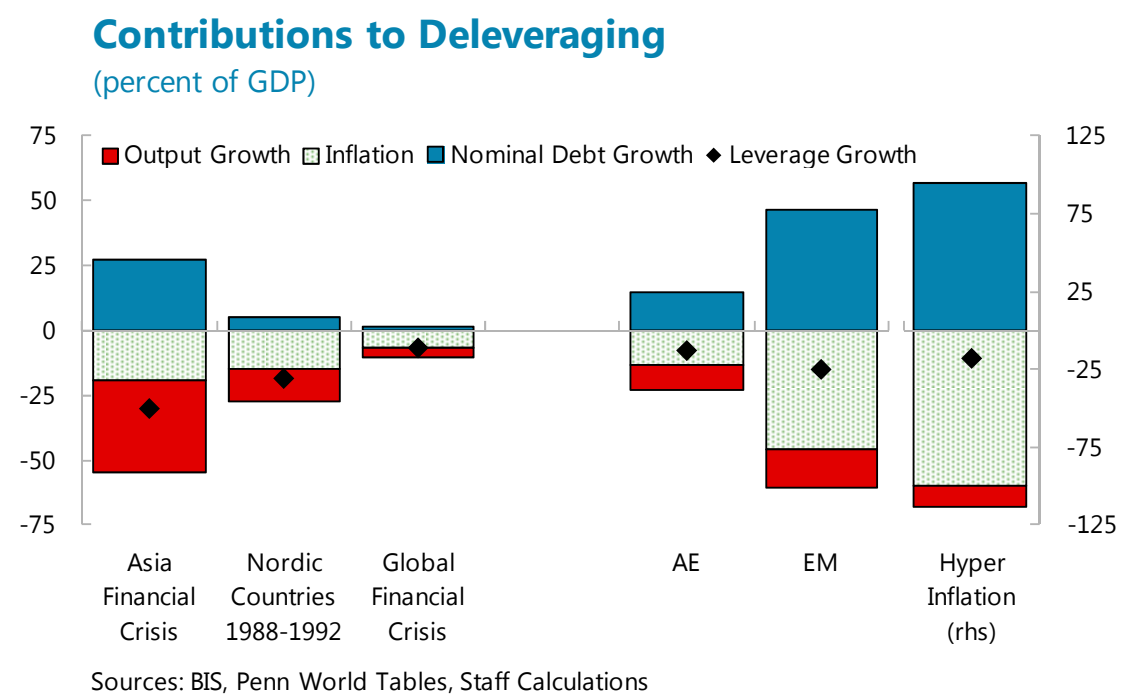

Cases of absolute reductions in nominal private sector debt over consecutive years are rare. The six episodes that saw absolute reductions in nominal debt levels - that is, end-of-period debt level was lower than that at the beginning of the episode - all occur in the 1990s in either Europe or East and Southeast Asia, ${ }^{7,8}$. Instead, nominal debt accumulation Average Annual Growth Rates generally remained positive in most cases, with deleveraging achieved primarily through higher income growth. On average the rate of nominal debt accumulation is about 3 percentage points lower than nominal GDP growth over the delveraging period (text chart). By comparison, debt accumulation was about 4 percentage points higher than nominal growth over five-year periods before and after these episodes.

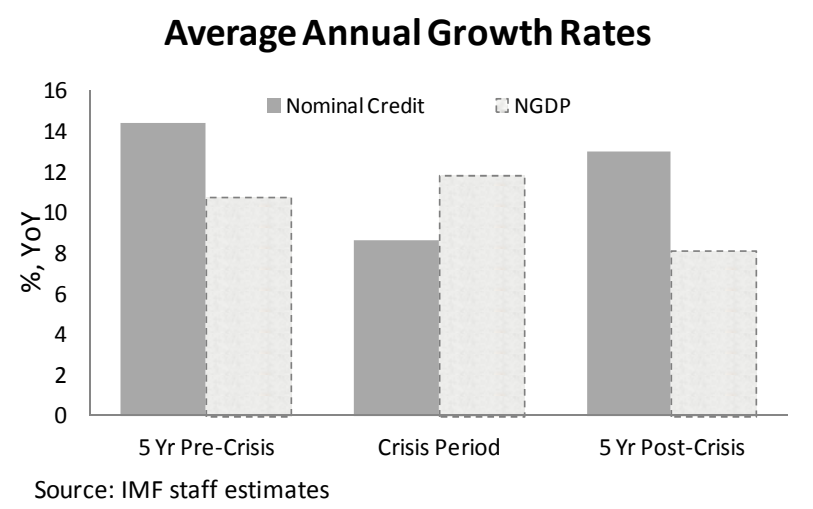

Deleveraging is observed mostly in the non-financial corporate sector (text chart). We compare household and corporate sector contributions to total deleveraging in the 37 cases for which we have a breakdown. Episodes with equal contributions from both sectors would fall on the 45

\footnotetext{
${ }^{7}$ The six episodes are: Finland 1992 (6 years of deleveraging), Hong Kong 1997 (5 years), Indonesia 1997 (5 years), Japan 1995 (12 years), Poland 2002 (2 years), and Thailand 1997 (10 years).

${ }^{8}$ By contrast, declines on a per year basis (relative to episodes) are more common. Out of the entire sample, 18 episodes saw a decline in debt levels during some parts of the episodes, though on net, the aggregate average rate of credit growth was positive for most of these cases.
} 
degree line, but only four episodes show equal or greater contributions from the household sector. In fact, 20 episodes show an increase in the household leverage ratios. This may reflect that the underlying increase in household leverage, a structural feature, is particularly strong, but it also highlights the challenges facing economies that experience housing busts, where it seems that household leverage typically adjusts much more slowly than that in other sectors. Indeed, the sector's apparent low cyclicality due to long debt maturity suggests that NFCs will remain the dominant drivers of private debt reduction.

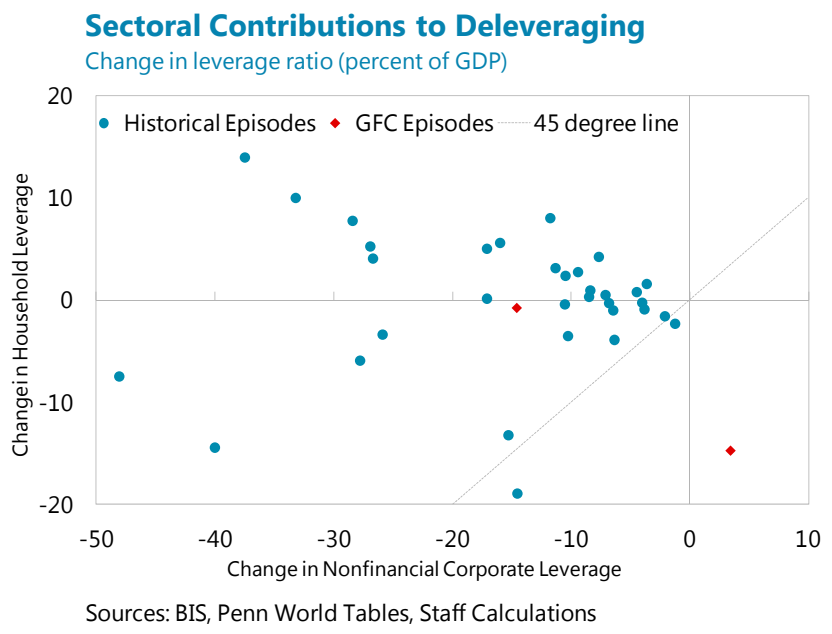

\section{E. Experience through the Global Financial Crisis}

The Global Financial Crisis has seen a cluster of deleveraging events. These episodes occur under unusually difficult macroeconomic conditions, including negative growth and low inflation or deflation. Indeed, the current deleveraging cycle, particularly in European countries under stress finds very few historical analogs in terms of negative growth. The levering-up phase was very strong and lasted well into the recession. In the early phase of the recession, economic decline outpaced reductions in private sector debt, leading to an increase in leverage ratios through 2010-11. Thus we are currently less than four years from most identified peaks.

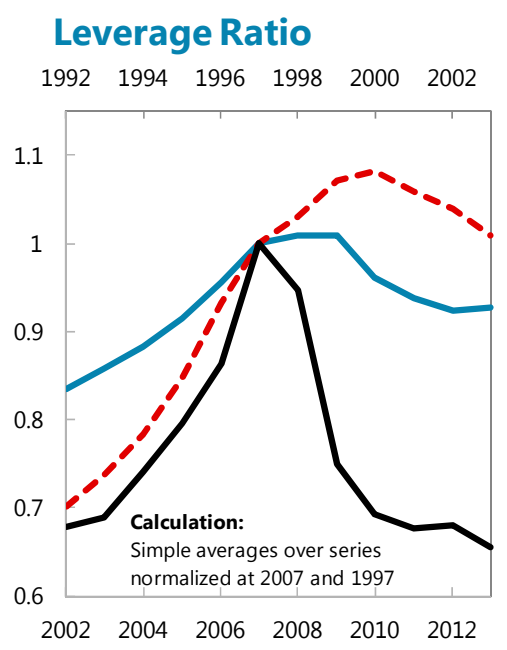

\section{Real GDP per Capita}
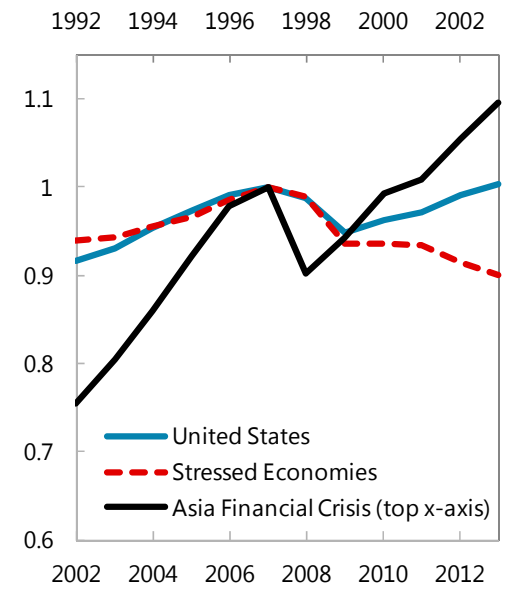

The chart above presents an average of stressed European economies' deleveraging experiences ${ }^{9}$ against other countries. For these European economies, private debt rose rapidly in

\footnotetext{
${ }^{9}$ Greece, Ireland, Italy, Portugal, and Spain
} 
advance of the crisis but has transitioned to a period of modest decline. Significant reductions in the debt stock paled in comparison to losses in real output.

The difference is especially stark when compared with either the Asian Financial Crisis or the United States during the GFC. During the Asian Financial Crisis, affordability ratios peaked in 1997 and saw a very quick decline of over 30 percentage points in the ensuing four years at the expense of a sharp output contraction between 1997 and 1998. Meanwhile the U.S. has seen some gradual reduction in leverage combined with a relatively stronger output performance, a sharp contrast with the lingering challenges in the European economies.

The experience of those countries that saw rapid deleveraging through the present crisis, particularly the U.S. and the U.K., are suggestive. Getting bad debt off private sector balance sheets appears correlated with recovery, presumably as it helps free-up an economy to invest and consume. These experiences are in line with the deep deleveraging and rapid recoveries in East Asia in the late 1990s. For a broader perspective, our sample provides an opportunity to compare this narrative against a large sample of deleveraging episodes over more than five decades across all types of countries.

That said, as with any set of cross-country growth correlations, there are many factors that may be behind this relationship, and a variety of confounding factors which may play a role. Indeed, a key challenge with this examination of deleveraging episodes is the lack of systematic data on private sector debt reduction operations - relief offered by the financial system to the real economy, whether through write-offs or net present value reduction of debt in debt restructuring. Without this, it is difficult to assess the impact of specific actions to promote deleveraging on subsequent output dynamics. In the next section we control for various factors that can be identified to isolate the role of deleveraging.

\section{Deleveraging Modality and Growth - An Empirical Analysis}

\section{A. Analytical Considerations}

We next examine empirically the extent to which greater private sector deleveraging is associated with higher subsequent growth. One consideration - as suggested by the literature -is the tradeoff between swift deleveraging and growth. Delay in balance sheet repair following an excessive credit boom could suppress demand and impair economic efficiency by locking up resources in unproductive sectors. At the same time, however, deleveraging could weigh on output growth as households and non-financial corporates undergo balance sheet adjustments. The net benefit of this trade-off is not obvious without taking a close look at the data.

We find in our sample that although a fall in debt level is associated with weaker growth, output losses associated with a decline in leverage ratios are rare. In part, as we showed in section III, deleveraging was largely achieved through more moderate debt accumulation relative to income growth. Out of the sample of 83 episodes, only one saw a negative annual real growth rate during the deleveraging period. A larger share - about 65 percent of the cases - saw weaker, but positive real annual growth relative to the five years before the onset of balance sheet adjustment. Still, given the unconditional correlation between debt accumulation and growth, it 
is possible that slower leverage growth could have dampened growth recovery. We explore this trade-off between deleveraging and growth in a robustness test.

Another consideration is the channels through which deleveraging takes place. If deleveraging is done through increased savings from households, the process could result in a sizable downturn in consumption ${ }^{10}$. Alternatively, if the process is achieved through default or loan forgiveness, the problem is shifted from consumers (who may still shoulder tax liabilities, legal fees and lower credit scores) to banks. Banks, in return, might have to curtail lending. Still, a third option could involve corporates, whose deleveraging could result in reduced investment. The question of who bears the burden can affect growth and the policy prescription. We explore the varying effects of different deleveraging agents in our robustness test, though granular data on sectoral breakdowns are few, thus limiting the generality of the results.

A third important consideration is the issue of reverse causality: sluggish growth may contribute to high debt ratios, or debt service burdens may constrain growth through limited consumption and investment. Other omitted factors may simultaneously reduce growth and increase debt. ${ }^{11}$ Our analysis does not formally establish a firm causality. Instead, given limited data, we allow for non-overlapping episodes - that is, we look at real growth per capita over $n$ years following deleveraging. We thus take the notable approach of a temporal separation between the growth variable (dependent) and the deleveraging variable (regressor). By focusing on the relationship between deleveraging and the subsequent medium-term growth, we seek to mitigate the problem associated with the direction of causality between leverage and growth. Finally, we analyze the impact of extreme deleveraging events that were not associated with a decline in growth, the associated changes in interest rates or with the occurrence of financial crises as another robustness check for assessing the link between deleveraging and subsequent growth.

Lastly, the extent to which a decline in credit is due to supply or demand factors affects growth prospects and policy responses. If limited credit is a result of reduced investment opportunities, leading to a fall in demand for credit, the attendant growth prospect could well be different from a supply shock, driven by, say, a tightening in bank lending standards. One study finds that in general, demand shocks to credit ${ }^{12}$ have longer lasting and stronger effects on real GDP than supply shocks (Chen et al., 2012). A novel approach may be to proxy supply shocks using bank loan write-offs. We do not make the distinction between supply and demand shocks in our study, however, as consistent, reliable data are lacking on a cross-country basis.

\footnotetext{
${ }^{10}$ In a sample of OECD countries from 1980 to 2012, Bouis (2014) found that the negative relationship between household savings rate and debt ratios is only significant during debt build-ups. The rise of savings rates during deleveraging period may reflect primarily an increase in precautionary saving, with little direct connection to changes in debt.

${ }^{11}$ In a study on U.S. households, consumption and employment fell more in those states that suffered larger housing busts (Mian \& Sufi, 2014). In another study on Spain, weakened employment prospects and reduced financing are associated with a decline in household savings (Sastre and Fernandez-Sanchez, 2011).

${ }^{12}$ Credit, in the study, is defined more broadly as a combination of bank credit and collateral-based funding; negative demand shock is identified as a decline in quantity and a corresponding decline in price.
} 


\section{B. Data}

We rely primarily on BIS data on credit to private non-financial sectors for our analysis. Although our policy discussion is mainly focused on the actual debt burden facing households and non-financial corporates, historical sectoral data collected from these entities are not available for most of our sample countries and are not fully comparable internationally even when available. ${ }^{13}$ In all, there are 36 countries in our sample, with annual data generally ranging from 1960 to 2013.

\section{Model Setup}

For our benchmark results, we estimate the following regression equation:

$$
\bar{y}_{i, T q+1-T q+5}=\beta_{0}+\beta_{1} \Delta d_{i, T 0-T q}+\sum \beta_{m} X_{i, m}+\varepsilon_{i}
$$

where $\bar{y}_{i, T q+1-T q+5}$ refers to the 5-year forward average output per capita growth rate on an annual basis (measured as log-difference) starting $q+1$ years after the end of a leverage cycle. ${ }^{14}$ The deleveraging variable $\Delta d_{i, T 0-T q}$ is analyzed from two perspectives: first, in a "fixed window" approach, we assess the impact of deleveraging over a five year horizon - based on the average duration of deleveraging - on subsequent growth over the next five years, that is, year 6 to year 10. This relatively simple approach allows us to estimate the impact of the size of deleveraging on growth. A second, more nuanced approach decomposes deleveraging into two components: the average deleveraging per year, that is, the intensity of deleveraging, measured as the percentage point change in the private sector debt-to-GDP ratio over the deleveraging period where a negative value denotes reduction in the debt ratio (i.e. "deleveraging"); and the total number of years spent delevering, where a positive number denotes increases in deleveraging duration.

We consider a number of regressors $\left(X_{i, m}\right)$ to control for the initial economic conditions and the domestic policy stance over the first $q$ years. For the former we consider: the per capita output growth rate from $\mathrm{T} 0$ to $\mathrm{T} q$ to capture any potential rebound effect in the subsequent period, the change in the real effective exchange rate over $\mathrm{T} 0-\mathrm{T} q$ to control for possible gain/loss of external price competitiveness, the private/public debt-to-GDP ratio at T0 as a measure of initial debt burden in the private and the public sector, and GDP per capita relative to the United States at $\mathrm{T} 0$ to reflect various structural differences between advanced and emerging market economies.

\footnotetext{
${ }^{13}$ Depending on the institutional arrangement of individual countries, this could potentially over-estimate the extent of actual debt reduction in household and corporate balance sheets in a leverage cycle downturn. For example, while mortgage loans in the United States are non-recourse, debt forgiveness policy is much stricter in Europe.

${ }^{14}$ As most countries in our sample have more than one deleveraging episode, we use the subscript $i$ to denote a leverage cycle and not a specific country.
} 
Having the output growth during the corresponding deleveraging years as a regressor is particularly important in this setup. Not only does this variable capture potential rebound effect following a deleveraging spell, but more importantly, it accounts for the positive correlation that exists between the average output growth rates in the two non-overlapping windows: countries with relatively high output growth over the deleveraging years tend to experience high growth over the subsequent years, and vice versa. This implies that, for a given average nominal debt stock over $\mathrm{T} 0-\mathrm{T} q$, a country with relatively high trend output growth would exhibit greater deleveraging (denominator effect) and faster subsequent recovery. In light of this output dynamics effect, we attempt to isolate the impact of deleveraging by including the average output growth during the initial deleveraging years and the relative level of GDP per capita as explanatory variables.

As for the policy variables, we consider the change in the short-term real interest rate and the government primary balance from $\mathrm{T} 0$ to $\mathrm{T} q$ to account for the extent of monetary and the fiscal policy stimulus, respectively.

Finally before turning to the results, we recognize that deleveraging does not occur in a vacuum but reacts to macroeconomic conditions; we therefore note a few important caveats in our analysis. First, although we use non-overlapping windows and control for the output growth in the initial deleveraging period, interpreting the results as a causal link between deleveraging and growth still warrants caution. Second, the small number of pre-GFC episodes (73) constrains the number of control variables that can be considered, such that potential omitted variable bias, and associated limitations on inference, cannot be excluded.

\section{Regression Results}

We present our benchmark regression results in Appendix 2, Table 1. Regressions for output use the ordinary least squares estimator and the Newey-West method for estimating robust standard errors of the coefficients.

In the fixed-window approach from the benchmark regression, the estimated coefficient for the deleveraging variable is negative and statistically significant, implying greater deleveraging tends to be followed by higher future growth in output. Furthermore, the size of the impact is also economically significant: a 10 percentage point decline in the private debt ratio over T0 T5 is related to about $30-42$ basis points higher average annual growth rate over the following 5 years (T6 - T10), which amounts to about 1.5 to 2 percentage point higher output level on a cumulative basis. Considering that the average decline in the debt ratio for the pre-GFC sample is about 15 percentage points, the average impact on the subsequent annual output growth would be about 45 basis points, which is not trivial especially when one considers that potential output growth rates for advanced economies are currently estimated at about 2 percent.

For a more disaggregated analysis of deleveraging, the efforts are decomposed into intensity the size of deleveraging per year over the episode - and duration - the length of deleveraging. The results are qualitatively the same as the benchmark regression for most of the regressors. The estimated coefficient for deleveraging intensity is negative and statistically significant, implying greater deleveraging intensity tends to be followed by higher future growth in output (Table 2). Furthermore, the size of the impact is also economically significant: a 1 percentage 
point decline in the private debt ratio per year over the deleveraging period is related to about 13 -24 basis points higher average annual growth rate over the following 5 years. As the average change in deleveraging intensity is a decline of about 3 percentage points per year, the cumulative boost to subsequent growth would amount to about 2 to 3 percentage points.

Meanwhile, the estimated coefficient for the length of deleveraging is negative, suggesting longer deleveraging is associated with lower output over the subsequent years. Though not statistically significant, the effect of long deleveraging duration is sizable economically: every year of deleveraging is associated with a subsequent output loss of 5 to as much as 12 basis points per year. Such a relationship between output and deleveraging duration supports the widely-held notion that deleveraging comes with a tradeoff; extended periods of deleveraging, either a result of institutional constraints or borrower inertia or both, prolongs the process needed to cleanse balance sheets, affects the allocation of capital and labor and correspondingly, the prospects for output. To the extent that deleveraging reflects active efforts to tackle the private sector debt burden, these results provide insights to the modality of deleveraging and empirical support to the argument that faster and more aggressive balance sheet repairs are needed to boost growth following a credit bust. ${ }^{15}$

As for other control variables, the coefficient for the average output growth over the corresponding deleveraging period is positive and highly significantly, accounting for most of the equation's explanatory power. The level of GDP per capita relative to the U.S. does not seem to have a significant impact on total private debt. This is possibly because the initial period output growth and the debt-to-GDP ratio already capture structural differences between advanced and emerging market economies, as both variables are higher for advanced economies. Meanwhile, real effective exchange rate depreciation has the expected negative sign, implying that depreciation over the deleveraging years is associated with higher output growth in the subsequent 5 years.

Moreover, the results show that a loosening in fiscal and monetary policy over the deleveraging period has a sizable positive economic impact on future growth: a 1 percentage point increase in the government primary balance as percent of GDP is associated with a 20 to 30 basis points increase in the average annual investment growth. Meanwhile, every 1 percent point decline in monetary policy rate is related to roughly 5 basis points in annual subsequent growth (Table 2).

Lastly, to assess the extent to which the length of deleveraging could affect the impact of deleveraging intensity on subsequent growth (based on the episode approach), we created an interaction term between intensity and length; these two variables are now measured as deviation from the average deleveraging intensity and duration, respectively. Coefficients for the interaction term correspond to the effect of deleveraging intensity on subsequent growth when deleveraging duration is above or below the mean. The results are in line with those from the baseline regression and confirm the notion that slower deleveraging is associated with weaker subsequent growth. The coefficients for deleveraging intensity remain consistently

\footnotetext{
${ }^{15}$ A study by Bech, Gambacorta, and Kharroubi (2012) also find evidence that a 10 percentage point decline in the debt-to-GDP ratio during a business cycle downswing accompanied by a financial crisis is associated with a 60 basis point increase in average output growth in the recovery phase.
} 
negative and statistically significant, and are largely in the same ballpark as the baseline regression. Specifically, every extra percentage point of deleveraging above the sample average is associated with an additional gain of about 14 to 28 basis points of real growth per year. Meanwhile, each extra year spent deleveraging beyond the sample average of 5 years is associated with an annual output loss of about 6 to 18 basis points. And, for those that delever at average speed, but spend more time deleveraging, each additional year of deleveraging above the mean of 5 years is associated with subsequent output loss of roughly 5 basis points per year (Appendix 2, Table 3).

\section{E. Robustness}

In light of the small sample size and the identification challenges, we conduct a number of checks to confirm the robustness of our benchmark results.

Length of Post Deleveraging Period. We examine the sensitivity of the results with respect to the choice of the period window following deleveraging, and compare results from the benchmark 5 year model to periods of $3,4,6$, and 7 years, respectively. The coefficient for deleveraging intensity remains negative and significant regardless of the window chosen, though the size of the impact seems to peak over a 5 year window and moderates over a longer period (text chart $\left.^{16}\right)$. Interestingly, the coefficients for the length of deleveraging suggest more negative growth impacts over shorter horizons, with the estimated coefficients stabilizing over a longer period. The results suggest that growth following deleveraging could take

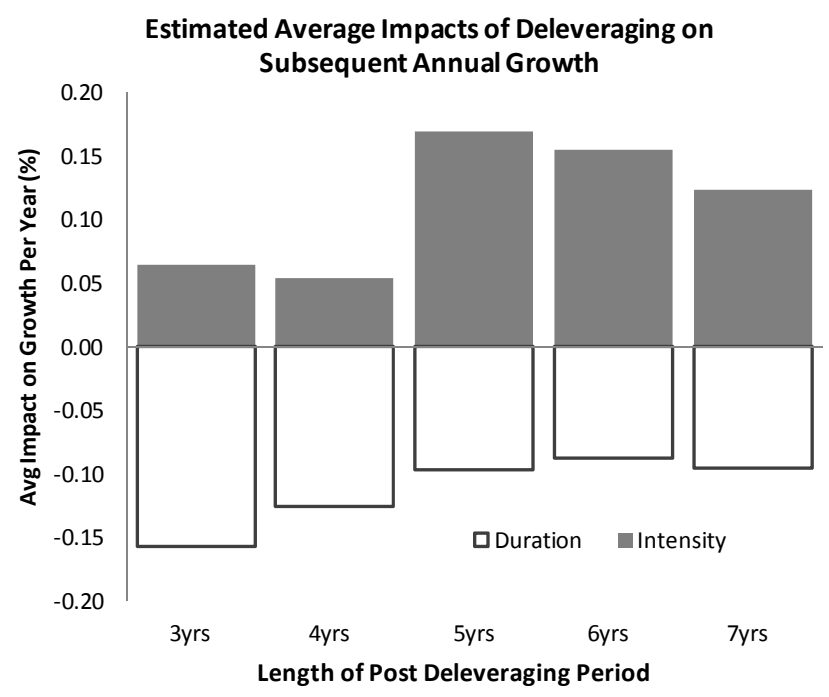
some time to recover, and confirm that on net, more aggressive and shorter deleveraging remains beneficial for subsequent growth.

Credit Gap. As an alternative to the private sector debt-to-GDP ratio, we consider the impact of the cyclical deviation in leverage ratios- measured as the percentage deviation of the ratio from trend. The motivation is to see whether, after accounting for the varying degrees of financial deepening - hence different trends - in our sample, the degrees of disequilibrium affects the modalities of deleveraging and correspondingly, subsequent growth. Put differently, increased financial market deepening is often thought to have promoted more efficient allocation of resources, accompanied by higher debt-to-asset levels; there is little evidence that the severity and length of recessions are correlated with the level of private sector debt - otherwise recessions would have shown increasing magnitude and duration, in line with the secular

\footnotetext{
${ }^{16}$ Coefficient signs for intensity are reversed to show positive impact on subsequent growth.
} 
increases in debt levels. But cyclical deviations in debt-to-asset levels relative to trend may heighten default probabilities through reduced collateral values at downturns and correspondingly, limited access to credit markets. The data on cyclical deviations suggest a positive relationship between the credit gap (i.e. higher leverage) at time of leverage cycle peak and total size of deleveraging. The equilibrium debt-to-income ratios may therefore be timevarying and dependent on economic fundamentals; the role of cyclical leverage relative to trend could be considered when assessing the impact of deleveraging on subsequent growth.

In this context, to more closely examine the role of cyclical fluctuations in leverage, we identify new deleveraging episodes using cyclical movements in leverage, where leverage ratios are detrended using the Christiano-Fitzgerald filter (Christiano \& Fitzgerald, 2001) ${ }^{17}$. The number of deleveraging episodes increased from 83 to 135 (Appendix I, Table 2). The episodes generally overlap with those from the benchmark model, though starting dates shifted somewhat. The length of deleveraging episodes increased slightly, from 4.7 years on average to 5.3 years, while the intensity of deleveraging fell slightly from an average of 3.6 percentage points to 2.9 percentage points. The regression results are qualitatively the same as the benchmark model. The impact of closing the credit gap on subsequent growth is sizable, ranging from 8 to about 20 basis points for every percentage points of narrowing in credit gap. Notably, the length of time spent deleveraging became statistically significant and the economic impact, larger. Each additional year spent closing the credit-gap is associated with subsequent output loss of 8 to slightly over 20 basis points per year (Appendix 2, Table 4).

Channels of deleveraging - households vs. nonfinancial corporate. To assess the sensitivity of investment and consumption to private sector deleveraging, we drilled down into the sectoral components of leverage cycles, decomposing them into changes in non-financial corporate and household leverage ratios, focusing on non-financial corporate debt to profit and household debt to gross deposable income (Appendix 1, Table 3 and 4, respectively). Given limited data, the number of deleveraging episodes falls considerably; for corporates, 40 episodes and for households, 17 episodes - compared to 83 episodes for total private debt. Excluding the Global Financial Crisis, the number of episodes falls to 33 and 12, respectively. The very limited number of household deleveraging episodes excludes empirical analysis. In the small sample of specifically corporate deleveraging episodes, there is little relationship between deleveraging and growth over the subsequent 5 years, in part, because investment dipped sizably within that window for a number of countries. If we shrink the post deleveraging window to three years, the relationship between deleveraging and growth became somewhat clearer. We found that the impact of deleveraging length has a dominant impact on future real investment growth, with consistently negative coefficients that are economically significant (Appendix 2, Table 5). Specifically, every year of deleveraging is associated with subsequent output loss of about, on average, 50 basis points per year. By contrast, the impact of deleveraging intensity is found to have little relationship with post deleveraging growth. A specific challenge with identification here may be that a large part of investment growth at cyclical frequencies may be explained by prospects for future aggregate growth.

\footnotetext{
${ }^{17}$ The filter cycles last between 5 and 32 quarters.
} 
Extreme deleveraging events. To address the potential issue of endogeneity between growth during the deleveraging period and the subsequent years as well as the issue of reverse causality between growth and leverage ratios, we also use an additional two-step approach focused on extreme shocks. The first step consists of estimating the drivers of episodes of private sector deleveraging using various explanatory variables, such as: contemporaneous and lagged GDP growth, changes in interest rates, inflation, or other structural features. As financial crises are also likely to affect private sector deleveraging, crisis dummies are also included among the explanatory variables. Extreme deleveraging events are then indicated using the residuals below the $5^{\text {th }}$ percentile. In all, there are 52 identified extreme deleveraging events, of which 20 in the household sector and 17 in the corporate sector (Appendix 3, Table 1). The second step focuses on deriving the impulse response functions of real (per capita) output to extreme deleveraging events. The results, attributable to sharp leverage reductions, are larger relative to the benchmark model and confirm that a reduction in the private sector debt has a significant and persistently positive effect on output. In particular, the occurrence of an extreme deleveraging episode increases real output by 0.6 percentage points after one year, or, a cumulative increase in real output of about 2.8 percent after 5 years. Interestingly, the effect seems to be driven by the corporate sector deleveraging rather than household (see Appendix 3 for more details).

Advanced vs. Emerging Market Economies. To see whether economic development matter, we divide our analysis between advanced and emerging market economies. In particular, using a two-step approach, we identify 29 exogenous deleveraging episodes in advanced countries and 23 in emerging economies. It appears that a sharp decrease in the private sector leverage has mostly a significant effect on output in emerging markets. In particular, an extreme deleveraging episode increases real output by 1.4 percent after one year with a 3-year cumulative impact of about 3.6 percent (text charts, Appendix 3).

Banking/Financial Crises. We examine whether the impact of deleveraging depends on the existence of a banking crisis using the dataset constructed by Laeven and Valencia (2012). It seems that the impact of a sharp reduction in private sector deleveraging on output is largerwith a 5-year cumulative increase of about 3.5 percent - when associated with bank restructuring, likely underscoring the important role of credit intermediation from banks. The effect, however, seems to be driven by advanced countries. In fact, private sector deleveraging has no significant impact on output when it is associated with banking crises in emerging markets. The striking difference between advanced economies and emerging economies suggests that the degree of financial deepening seems to play a role in the propagation of financial crises to the real economy.

Deleveraging/Growth Trade-off. Lastly, we return to the trade-off between deleveraging's potential short-term costs and long-run benefits for growth. In our benchmark regressions we seek to gauge causality by measuring output growth after the deleveraging episode concludes. For potential output losses concurrent with deleveraging we cannot establish causality. By assuming that the causality runs exclusively from deleveraging to growth, however, we can establish an upper bound on the potential short-run costs of deleveraging. To do so we simply rerun our benchmark regression with in-episode growth as the dependent variable and compare these results with those of the benchmark. The estimated effect of deleveraging intensity is highly unstable across regression specifications in the in-episode estimate, compared to positive and significant effects seen in the post-episode exercise across all specifications. This, in part, 
could be related to findings from Section III, which noted that in practice, deleveraging is brought on largely through lower borrowing and higher income growth. The net effect of deleveraging - the difference in coefficients between the two exercises-does confirm that that deleveraging, though likely to dampen growth in the short run, is associated with output gains overall (left-hand side text chart). Meanwhile, the effect of time spent deleveraging is unequivocally associated with output losses, though the in-episode impact is larger (right-hand side text chart).
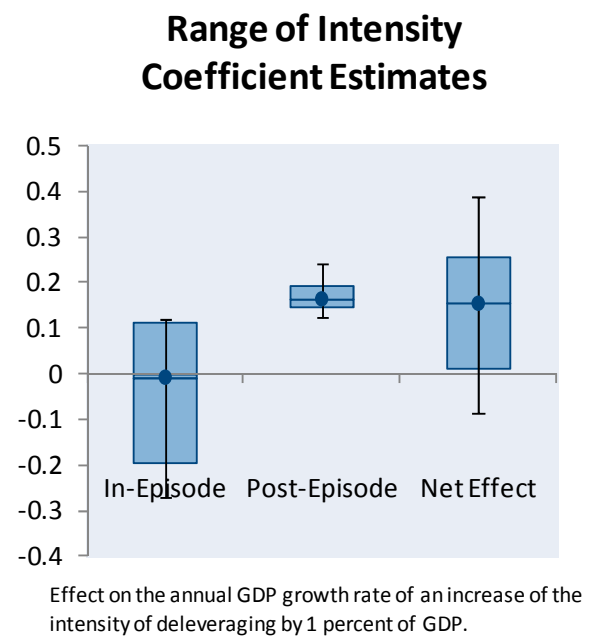

Range of Duration Coefficient Estimates

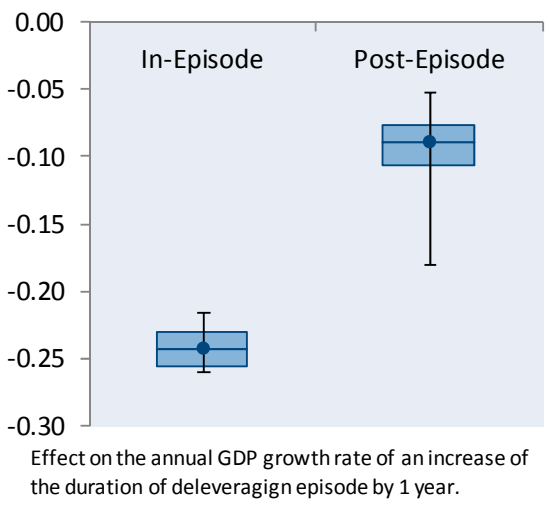

V. Conclusion

In this paper we have looked at the experience with private-sector leverage cycles across 36 countries over a span of 50 years and sought to assess how the modalities of deleveraging in the bust-phase of cycles affects subsequent economic growth.

Private sector debt has been rising on a secular basis, reflecting growing income levels and financial development. But this trend belies slow moving leverage cycles where leverage ratios tend to peak about every 19 years. Deleveraging experiences are therefore not uncommon and indeed most deleveraging episodes end within 5 years. Meanwhile, although total deleveraging size tends to increase with the length of adjustment, there does not appear to be a relationship between the intensity of deleveraging per year and the length of time spent deleveraging. Specifically, some of the sharpest reductions in leverage took place within two or three years, and some of the longest deleveraging spells were just as vigorous. Further, although deleveraging episodes were widely distributed across time, they became more synchronized around the late 1990s and most recently, during the Global Financial Crisis.

Looking at the impact of deleveraging, we find that larger deleveraging is positively associated with subsequent growth. Specifically, a 10 percentage point reduction in the leverage ratio over the 5 years of the typical episode is associated with an increase in annual growth of about 0.4 percentage points, such that the level of output would be about 2 percentage points higher over the subsequent 5-year period. In the more granular episode-based approach, the interpretation is more complex, but also intuitive. Greater intensity in deleveraging - i.e. higher per annum reduction in leverage - is associated with faster subsequent growth. But there is a trade-off 
against the time spent deleveraging - the more stretched out the time spent deleveraging is, the lower the subsequent growth. More specifically, a 1 percentage point decline in private sector debt ratio per year during the episode is associated with $13-24$ basis points increase in average annual real growth rate in the 5 years following the end of the episode. Considering that the average decline in the debt ratio per year for the sample pre-Global Financial Crisis (73 episodes spanning 36 countries) is about 3 percentage points, the average impact on the subsequent annual output growth would be about 30 to 70 basis points per year, hardly trivial. On the other hand, every year spent deleveraging is expected to trim as much as 12 basis points from subsequent growth per year. In this context, those that experienced shorter deleveraging episodes - relative to the average duration of 5 years - saw a boost to subsequent annual growth of about 5 basis points for every year below average duration.

A key challenge that we leave for future work is seeking to identify how much of the reduction in leverage observed in the episodes considered reflects the outcome of active efforts or policies to reduce firms and household debt burdens. To assess this we would need to have comprehensive data on the dynamics of debt related to real growth - interest differentials, savings, and then overlaid with data on debt reduction operations. In practice, non-financial sector nominal debt stock reduction is observed through internal savings, explicit write-downs of debt, ${ }^{18} \mathrm{NPV}$ reductions delivered through debt restructuring, and other modalities that could involve structured finance operations. In the Euro Area, for example, recent private sector deleveraging has been assisted, in part, by moving debt to the public sector's balance sheet through banking sector recapitalization, or debt-financed fiscal demand support (IMF 2013).

In the current context in advanced economies, this paper has documented that private sector balance sheet restructuring has been limited, albeit larger gains have been realized in the U.S. and the U.K. This may reflect the inherent difficulty of adjusting private debt stocksrestructuring requires the complex coordination between disparate stakeholders. And, it often calls for the substitution of private for public debt, a difficult task given the outlook for many sovereign balance sheets. But this paper has provided suggestive evidence of the gains that could be achieved by policies aimed at facilitating faster balance sheet realignments.

Specifically, research has highlighted the importance of easing liquidity constraints and facilitating debt restructuring (Andritzky, 2014; IMF 2015), including strengthening incentives for decentralized debt resolution by bolstering the legal and institutional framework and market infrastructures for NPL resolutions (IMF 2013; Jassaud and Kang, forthcoming). These will remain important policy objectives and likely key to facilitating higher growth in advanced economies going forward.

\footnotetext{
${ }^{18}$ For example McKinsey (2012) note that of the 15 percentage point reduction of debt relative to disposable income in U.S. households after the GFC, about two-thirds of which was a result of households walking away from foreclosed mortgages and other consumer debt. This reflects that mortgages in many U.S. jurisdictions are nonrecourse in nature, such that under-water households may vacate the property and see their debt effectively written down by their financiers.
} 


\section{REFERENCES}

Abiad, A., G. Dell'Ariccia, and B.Li, 2011, “Creditless Recoveries”, IMF Working Paper No. 11/58 (International Monetary Fund: Washington, DC).

Ali Abbas, S., B. Akitoby, J. Andritzky, H. Berger, T. Komatsuzaki, and J. Tyson, 2013, "Dealing with High Debt in an Era of Low Growth", IMF Staff Discussion Note, 13/07 (Washington, International Monetary Fund)

Albuquerque, B., U. Baumann, and G. Krustev, 2014, "Has US Household Deleveraging Ended? A Model-Based Estimate of Equilibrium Debt”, ECB Working Paper No. 1643

Andritzky, J., 2014, “Resolving Residential Mortgage Distress: Time to Modify?”, IMF Working Paper No. 14/226 (International Monetary Fund: Washington, DC).

Baum, A., C. Checherita, and P. Rother, 2013, "Debt and Growth: New Evidence from the Euro Area", Journal of International Money and Finance, Vol. 32, pp. 809-21.

Bech, M., L. Gambacorta and E. Kharroubi, 2012, "Monetary Policy in a Downturn: Are Financial crises Special?” BIS Working Paper No. 388

Benito, A., M. Waldron, G. Young and F. Zampolli, 2007, "The Role of Household Debt and Balance Sheets in the Monetary Transmission Mechanism", Bank of England Quarterly Bulletin, 47(1), 70-78.

Bouis, R., 2014, "Household Deleveraging and Savings Rates: A Cross-Country Analysis", (Forthcoming).

Calvo, G., A. Izquierdo, and E. Talvi, 2006, "Sudden Stops and Phoenix Miracles in Emerging Markets", American Economic Review Papers and Proceedings, Vol. 96, No.2, pp.40510.

Cecchetti, S., M. Mohanty, and F. Zampolli, 2011, "The Real Effects of Debt”, BIS Working Papers No 352

Chen, S., P. Liu, A. Maechler, C. Marsh, S. Saksonovs, and H.S. Shin, 2012, "Exploring the Dynamics of Global Liquidity", IMF Working Paper No. 12/246 (International Monetary Fund: Washington, DC).

Christiano, L. and T. Fitzgerald, 2003, “The Band Pass Filter”, International Economic Review, Vol. 44, No. 2, pp. 435 - 465

Claessens, S., M. Kose, and M. Torrones, 2011, “Financial Cycles: What? How? When?”, IMF Working Paper No. 11/76 (International Monetary Fund: Washington, DC). 
Dynan, K. and D. Kohn, 2007, "The Rise in U.S. Household Indebtedness: Causes and Consequences", Finance and Economics Discussion Series, 2007-37, Board of Governors (Federal Reserve: Washington, DC)

Eggertson, G., and P. Krugman, 2010, "Debt, Deleveraging, and the Liquidity Trap: A FisherMinsky-Koo Approach”, Quarterly Journal of Economics, Vol. 127, Issues 3, pp. 1469 1513

Federal Reserve Bank of Boston, 2013, “Assessing the Affordability of State Debt”, New England Public Policy Center, Research Report 13-2, December 2013 (Boston, MA)

Friedman, Benjamin M., "Increasing Indebtedness and Financial Stability in the United States," NBER working paper, No. 2072 (NBER: Cambridge, MA)

Gourinchas, P.O. and M. Obstfeld, 2012, "Stories of the Twentieth Century for the TwentyFirst", American Economic Journal: Macroeconomics, American Economic Association, vol. 4(1), pp. 226-65

Harding, D. and A. Pagan, 2002, "Dissecting the cycle: A methodological investigation", Journal of Monetary Economics (49), 365- 381

International Monetary Fund, 2012, "Dealing with Household Debt", Chapter 3, World Economic Outlook”, April 2012 (International Monetary Fund: Washington, DC).

International Monetary Fund, 2013, "Indebtedness and Deleveraging in the Euro Area" Chapter 3 Euro Area: Selected Issues Paper, IMF Country Report No. 13/232 (International Monetary Fund: Washington, DC).

International Monetary Fund, 2015, "Housing Recoveries: Cluster Report on Denmark, Ireland, the Netherlands, and Spain”, IMF Country Report No. 15/1 (International Monetary Fund: Washington, DC).

Jordà, O., 2005, "Estimation and inference of impulse responses by local projections," American Economic Review 95 (1), 161-182.

Jordà, O., M. Schularick, and A.M. Taylor, 2010, "Financial Crises, Credit Booms, and External Imbalances: 140 Years of Lessons," NBER Working Paper No. 16567 (NBER: Cambridge, MA)

Jassaud, N. and K. Kang, "A Strategy for Developing a Market for Distressed Debt in Italy", IMF Working Paper, forthcoming (International Monetary Fund: Washington, DC).

Kiyotaki, N. and J. Moore, 1997, “Credit Cycles” Journal of Political Economy, Vol. 105, No. 2, pp. 211-48 
Laeven, L. and F. Valencia, 2011, "The Real Effects of Financial Sector Interventions During Crises” IMF Working Paper No. 11/45 (International Monetary Fund: Washington DC).

McKinsey Global Institute, 2012, Debt and Deleveraging: Uneven progress on the path to growth, McKinsey \& Company

Meltzer, B. T., 2010, “Mortgage Debt Overhang: Reduced Investment by Homeowners with Negative Equity”, Faculty Paper, Northwestern University, Kellogg Business School, August 2010

Mian, A., K. Rao and A. Sufi (2011): What Explains High Unemployment? The Aggregate Demand Channel," University of Chicago Booth School Working Paper, November

Mian, A., and A. Sufi (2014): House of Debt: How They (and You) Caused the Great Recession, and How We Can Prevent It From Happening Again, University of Chicago Press

Kumar, M. and J. Woo, 2010, "Public Debt and Growth", IMF Working Paper No. 10/174 (International Monetary Fund: Washington, DC).

Pescatori, A., D. Sandri, and J. Simon, 2014, "Debt and Growth: Is There a Magic Threshold?" IMF Working Paper No. 14/34 (International Monetary Fund: Washington, DC).

Philippon, T., and V. Midrigan, 2011, "Household Leverage and Recession” NBER Working Paper No. 16965 (NBER: Cambridge, MA)

Randveer, M., L. Uusküla and L. Kulu , 2011, "The Impact of Private Debt on Economic Growth”, Bank of Estonia Working Paper 10/2011

Reinhart, C. and K. Rogoff, 2010, "Growth in a Time of Debt", American Economic Review: Papers \& Proceedings, Vol. 100, No.2, pp.573-78.

Sastre, T. and Fernandez-Sanchez, J. L. (2011), “The Savings Rate During the Economic Crisis: The Role of Unemployment Expectations and Financing” Bank of Spain Economic Bulletin, November 2011

Takáts, E. and C. Upper, 2013, "Credit and Growth After Financial Crises”, BIS Working Paper No. 416

Tang, G. and C. Upper, 2010, “Debt reduction After Crises”, BIS Quarterly Review, September 2010 , pp. $25-38$

Tirole, Jean, 2011, "Illiquidity and All its Friends," Journal of Economic Literature, Vol. 49, Number 2, pp. 287-325. 


\section{APPENDIX 1: LEVERAGE EPISODES}

Table 1. Episode List - Changes in Private Debt/Nominal GDP

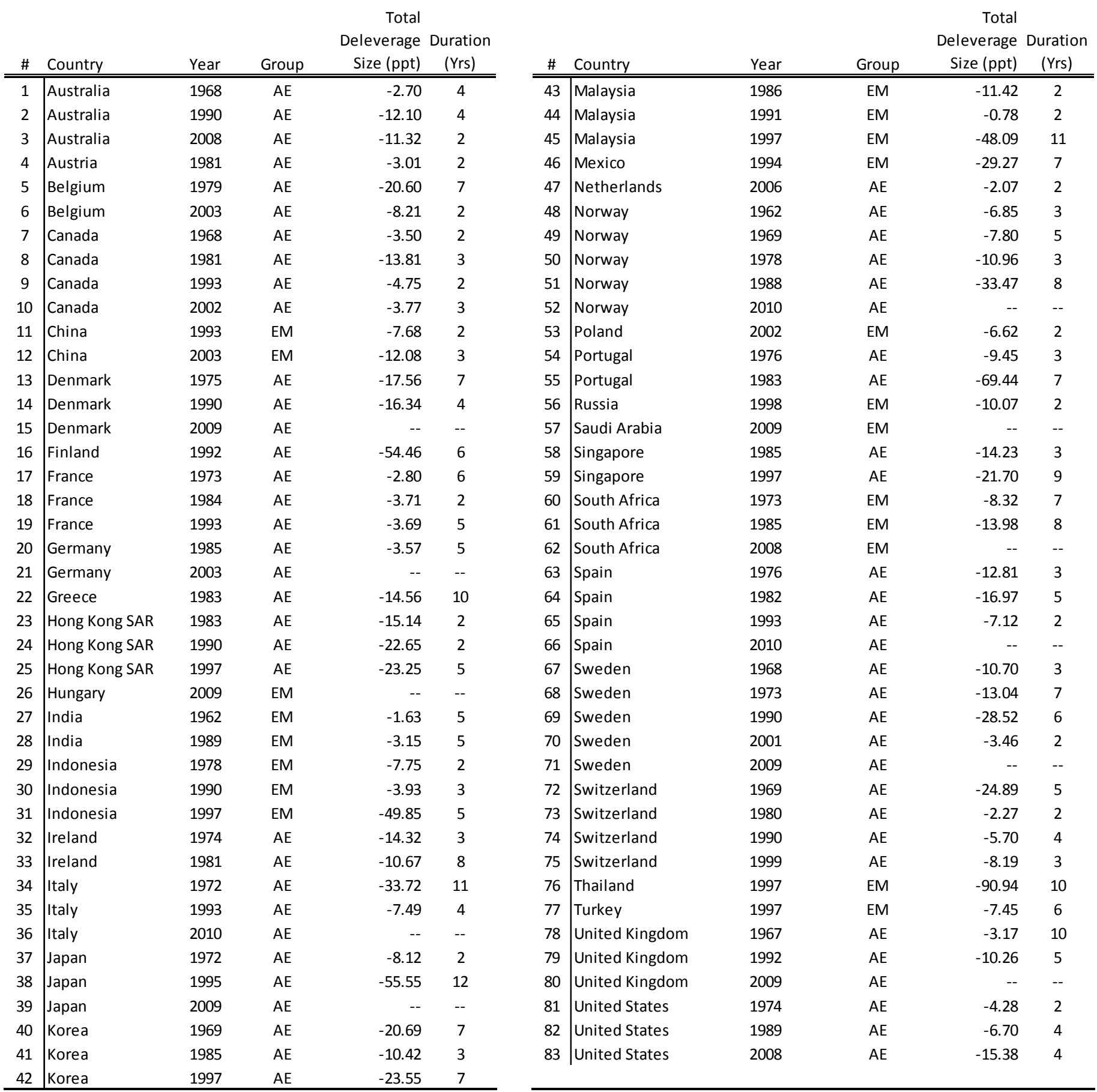


Table 2. Episode List - Cyclical Changes in Private Debt/Nominal GDP

\begin{tabular}{|c|c|c|c|c|c|c|c|c|c|c|c|}
\hline$\#$ & Country & Year & $\begin{array}{r}\text { Total Private } \\
\text { Debt/NGDP (\%) } \\
\text { at } \mathrm{T}_{0} \\
\end{array}$ & $\begin{array}{r}\text { Total } \\
\text { deleveraging } \\
\text { size }(\mathrm{ppt}) \\
\end{array}$ & $\begin{array}{r}\text { Duration } \\
\text { (years) } \\
\end{array}$ & 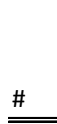 & Country & Year & $\begin{array}{r}\text { Total Private } \\
\text { Debt/NGDP (\%) } \\
\text { at } \mathrm{T}_{0} \\
\end{array}$ & $\begin{array}{r}\text { Total } \\
\text { deleveraging } \\
\text { size }(\mathrm{ppt}) \\
\end{array}$ & $\begin{array}{r}\text { Duration } \\
\text { (years) } \\
\end{array}$ \\
\hline 1 & Australia & 1967 & 62 & -7 & 5 & 53 & United Kingdom & 1990 & 134 & -39 & 8 \\
\hline 2 & Australia & 1975 & 67 & -7 & 3 & 54 & United Kingdom & 2008 & 208 & -- & -- \\
\hline 3 & Australia & 1989 & 115 & -27 & 6 & 55 & Greece & 1971 & 42 & -2 & 3 \\
\hline 4 & Australia & 2008 & 187 & -- & -- & 56 & Greece & 1983 & 51 & -4 & 15 \\
\hline 5 & Austria & 1966 & 44 & -2 & 2 & 57 & Greece & 2009 & 122 & -- & -- \\
\hline 6 & Austria & 1971 & 56 & -5 & 4 & 58 & Hong Kong SAR & 1982 & 127 & -28 & 4 \\
\hline 7 & Austria & 1980 & 86 & -10 & 6 & 59 & Hong Kong SAR & 1990 & 163 & -26 & 3 \\
\hline 8 & Austria & 1990 & 106 & -8 & 6 & 60 & Hong Kong SAR & 1997 & 180 & -37 & 5 \\
\hline 9 & Austria & 2001 & 139 & -7 & 4 & 61 & Hong Kong SAR & 2005 & 172 & -2 & 2 \\
\hline 10 & Austria & 2010 & 164 & -- & -- & 62 & Hungary & 2009 & 170 & -- & -- \\
\hline 11 & Belgium & 1972 & 86 & -2 & 2 & 63 & Indonesia & 1991 & 54 & -6 & 2 \\
\hline 12 & Belgium & 1979 & 107 & -23 & 7 & 64 & Indonesia & 1997 & 76 & -42 & 4 \\
\hline 13 & Belgium & 1991 & 104 & -8 & 5 & 65 & India & 1971 & 14 & -1 & 3 \\
\hline 14 & Belgium & 2001 & 179 & -20 & 5 & 66 & India & 1988 & 29 & -6 & 10 \\
\hline 15 & Canada & 1967 & 90 & -4 & 3 & 67 & India & 2001 & 33 & -1 & 2 \\
\hline 16 & Canada & 1973 & 100 & 0 & 2 & 68 & India & 2008 & 55 & -- & -- \\
\hline 17 & Canada & 1980 & 122 & -24 & 5 & 69 & Ireland & 1974 & 96 & -8 & 3 \\
\hline 18 & Canada & 1992 & 150 & -12 & 3 & 70 & Ireland & 1986 & 88 & -11 & 3 \\
\hline 19 & Canada & 1997 & 151 & -17 & 8 & 71 & Ireland & 1992 & 100 & -20 & 4 \\
\hline 20 & Canada & 2010 & 191 & -- & -- & 72 & Ireland & 1999 & 150 & -33 & 5 \\
\hline 21 & Switzerland & 1969 & 134 & -25 & 5 & 73 & Ireland & 2010 & 338 & -- & -- \\
\hline 22 & Switzerland & 1979 & 144 & -11 & 6 & 74 & Italy & 1973 & 86 & -19 & 8 \\
\hline 23 & Switzerland & 1990 & 186 & -13 & 4 & 75 & Italy & 1992 & 77 & -19 & 6 \\
\hline 24 & Switzerland & 1996 & 186 & -8 & 6 & 76 & Italy & 2001 & 86 & 1 & 2 \\
\hline 25 & Switzerland & 2004 & 183 & -6 & 3 & 77 & Italy & 2009 & 128 & -- & -- \\
\hline 26 & China & 1987 & 77 & -2 & 2 & 78 & Japan & 1966 & 123 & -7 & 3 \\
\hline 27 & China & 1992 & 85 & -15 & 3 & 79 & Japan & 1972 & 146 & -22 & 8 \\
\hline 28 & China & 1998 & 104 & -4 & 3 & 80 & Japan & 1983 & 162 & -1 & 2 \\
\hline 29 & China & 2003 & 128 & -27 & 4 & 81 & Japan & 1994 & 221 & -37 & 11 \\
\hline 30 & Czech Republic & 1997 & 81 & -15 & 7 & 82 & Korea & 1969 & 72 & -40 & 8 \\
\hline 31 & Germany & 1968 & 82 & -2 & 3 & 83 & Korea & 1984 & 101 & -21 & 4 \\
\hline 32 & Germany & 1973 & 90 & -3 & 4 & 84 & Korea & 1992 & 132 & -4 & 2 \\
\hline 33 & Germany & 1983 & 107 & -12 & 8 & 85 & Korea & 1997 & 170 & -44 & 8 \\
\hline 34 & Germany & 2002 & 136 & -- & -- & 86 & Korea & 2009 & 193 & -- & -- \\
\hline 35 & Denmark & 1968 & 115 & -2 & 3 & 87 & Mexico & 1994 & 48 & -27 & 9 \\
\hline 36 & Denmark & 1974 & 134 & -35 & 9 & 88 & Malaysia & 1970 & 22 & -11 & 8 \\
\hline 37 & Denmark & 1988 & 162 & -32 & 10 & 89 & Malaysia & 1985 & 85 & -23 & 8 \\
\hline 38 & Denmark & 2008 & 261 & -- & -- & 90 & Malaysia & 1997 & 159 & -49 & 9 \\
\hline 39 & Spain & 1975 & 106 & -13 & 4 & 91 & Netherlands & 1963 & 45 & -8 & 8 \\
\hline 40 & Spain & 1983 & 103 & -14 & 4 & 92 & Netherlands & 1980 & 100 & -17 & 6 \\
\hline 41 & Spain & 1990 & 95 & -22 & 7 & 93 & Netherlands & 1989 & 127 & -14 & 7 \\
\hline 42 & Spain & 2008 & 221 & -- & -- & 94 & Netherlands & 2004 & 203 & -5 & 3 \\
\hline 43 & Finland & 1977 & 90 & -10 & 6 & 95 & Netherlands & 2010 & 222 & -- & -- \\
\hline 44 & Finland & 1992 & 167 & -47 & 9 & 96 & Norway & 1962 & 112 & -6 & 3 \\
\hline 45 & Finland & 2010 & 178 & -- & -- & 97 & Norway & 1967 & 106 & -5 & 7 \\
\hline 46 & France & 1973 & 88 & -8 & 8 & 98 & Norway & 1977 & 126 & -18 & 4 \\
\hline 47 & France & 1983 & 88 & -3 & 3 & 99 & Norway & 1988 & 167 & -44 & 7 \\
\hline 48 & France & 1991 & 105 & -16 & 7 & 100 & Norway & 1998 & 159 & -5 & 3 \\
\hline 49 & France & 2001 & 124 & -5 & 3 & 101 & Norway & 2009 & 219 & -- & -- \\
\hline 50 & France & 2010 & 158 & -- & -- & 102 & Poland & 2001 & 42 & -11 & 4 \\
\hline 51 & United Kingdom & 1967 & 63 & -5 & 3 & 103 & Poland & 2009 & 71 & -- & -- \\
\hline 52 & United Kingdom & 1973 & 69 & -20 & 7 & 104 & Portugal & 1964 & 82 & -5 & 4 \\
\hline
\end{tabular}


Table 2 - Cont'd. Episode List - Cyclical Changes in Private Debt/Nominal GDP (2)

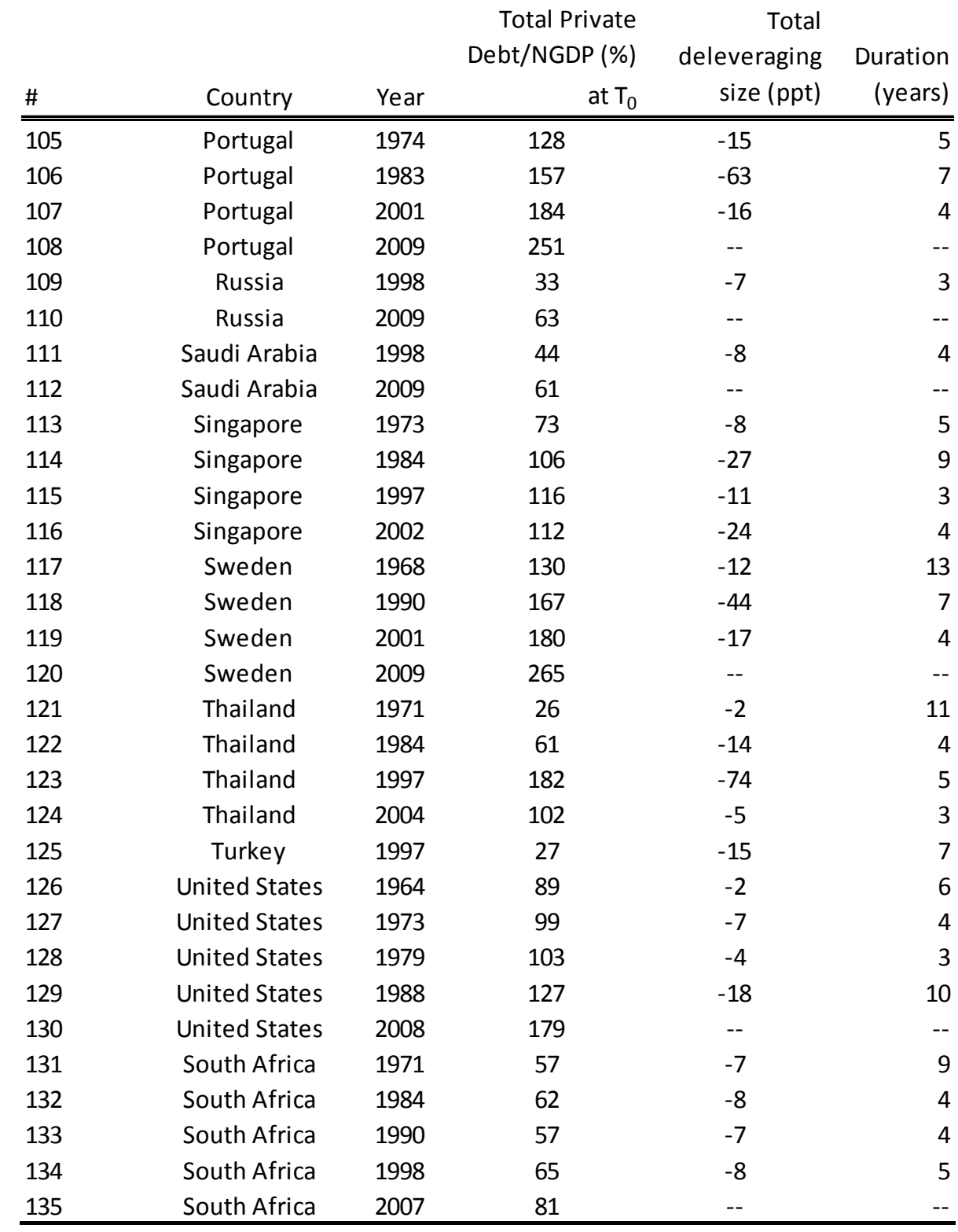


Table 3. Episode List - Changes in NFC Debt/Profit

\begin{tabular}{|c|c|c|c|c|c|}
\hline \# & Country & Year & $\begin{array}{c}\text { Debt/Profit (\%) } \\
\text { at } \mathrm{T}_{0}\end{array}$ & $\begin{array}{c}\text { Deleveraging Size } \\
\text { (ppt) }\end{array}$ & $\begin{array}{c}\text { Duration } \\
\text { (years) }\end{array}$ \\
\hline 1 & Australia & 1982 & 191 & -11 & 2 \\
\hline 2 & Australia & 1990 & 252 & -64 & 5 \\
\hline 3 & Australia & 2001 & 207 & -13 & 2 \\
\hline 4 & Australia & 2008 & 246 & -- & -- \\
\hline 5 & Austria & 2001 & 244 & -26 & 5 \\
\hline 6 & Belgium & 2003 & 422 & -48 & 2 \\
\hline 7 & Canada & 1992 & 456 & -127 & 8 \\
\hline 8 & Canada & 2002 & 362 & -72 & 3 \\
\hline 9 & Canada & 2009 & 381 & -- & -- \\
\hline 10 & China & 2009 & 1228 & -272 & 1 \\
\hline 11 & Germany & 1993 & 162 & -21 & 2 \\
\hline 12 & Germany & 2003 & 173 & -27 & 4 \\
\hline 13 & Germany & 2009 & 163 & -- & -- \\
\hline 14 & Spain & 1992 & 183 & -41 & 3 \\
\hline 15 & Spain & 2010 & 346 & -- & -- \\
\hline 16 & Finland & 1977 & 197 & -29 & 2 \\
\hline 17 & Finland & 1992 & 377 & -171 & 6 \\
\hline 18 & France & 1983 & 185 & -23 & 3 \\
\hline 19 & France & 1992 & 194 & -6 & 6 \\
\hline 20 & France & 2002 & 235 & -4 & 1 \\
\hline 21 & United Kingdom & 1992 & 323 & -83 & 5 \\
\hline 22 & United Kingdom & 2002 & 421 & -43 & 2 \\
\hline 23 & Italy & 1988 & 119 & -11 & 1 \\
\hline 24 & Italy & 1993 & 133 & -25 & 3 \\
\hline 25 & Japan & 1975 & 3345 & -1997 & 5 \\
\hline 26 & Japan & 1986 & 1917 & -461 & 3 \\
\hline 27 & Japan & 1993 & 3394 & -2543 & 14 \\
\hline 28 & Japan & 2009 & 1767 & -- & -- \\
\hline 29 & Netherlands & 1993 & 237 & -20 & 4 \\
\hline 30 & Netherlands & 2001 & 267 & -36 & 7 \\
\hline 31 & Netherlands & 2009 & 254 & -- & -- \\
\hline 32 & Norway & 1988 & 498 & -202 & 8 \\
\hline 33 & Norway & 1998 & 464 & -179 & 8 \\
\hline 34 & Norway & 2009 & 472 & -- & -- \\
\hline 35 & Sweden & 2001 & 441 & -57 & 3 \\
\hline 36 & Sweden & 2009 & 654 & -101 & 1 \\
\hline 37 & United States & 1974 & 152 & -18 & 2 \\
\hline 38 & United States & 1988 & 174 & -29 & 6 \\
\hline 39 & United States & 2001 & 181 & -12 & 3 \\
\hline 40 & United States & 2008 & 207 & -16 & 2 \\
\hline
\end{tabular}


Table 4. Episode List - Changes in HH Debt/GDI

\begin{tabular}{|c|c|c|c|c|c|}
\hline \multirow[b]{3}{*}{ \# } & \multirow[b]{3}{*}{ Country } & \multirow[b]{3}{*}{ Date } & \multicolumn{2}{|r|}{ Total } & \multirow{3}{*}{$\begin{array}{r}\text { Duration } \\
\text { (Years) }\end{array}$} \\
\hline & & & \multicolumn{2}{|c|}{$\mathrm{HH}$ debt/GDI deleveraging size } & \\
\hline & & & (\%) at $\mathrm{T}_{0}$ & (ppt) & \\
\hline 1 & Belgium & 1999 & 64 & -5 & 2 \\
\hline 2 & Canada & 1999 & 104 & -1 & 2 \\
\hline 3 & Switzerland & 2005 & 185 & -8 & 3 \\
\hline 4 & Germany & 1986 & 90 & -13 & 5 \\
\hline 5 & Germany & $2000^{1}$ & 108 & Note 1 & Note 1 \\
\hline 6 & Finland & 1989 & 78 & -23 & 8 \\
\hline 7 & France & 1993 & 55 & -2 & 2 \\
\hline 8 & United Kingdom & 1990 & 104 & -10 & 7 \\
\hline 9 & United Kingdom & 2008 & 156 & ongoing & ongoing \\
\hline 10 & Hungary & 2010 & 69 & ongoing & ongoing \\
\hline 11 & Italy & 1993 & 26 & -2 & 2 \\
\hline 12 & Japan & 1990 & 111 & -3 & 2 \\
\hline 13 & Japan & $2000^{1}$ & 116 & Note 1 & Note 1 \\
\hline 14 & United States & 1965 & 65 & -6 & 5 \\
\hline 15 & United States & 1973 & 61 & -2 & 2 \\
\hline 16 & United States & 1979 & 69 & -6 & 3 \\
\hline 17 & United States & 2007 & 127 & ongoing & ongoing \\
\hline
\end{tabular}

Note 1: German and Japanese household debt ratios have been on a secular downward trend since 2000, with the latest 2013 data suggesting ongoing declines. 


\section{APPENDIX 2: REGRESSION RESULTS}

Table 1. Impact of Deleveraging on Future Output Growth from Year 6 to Year 10 - (Nominal Private Debt/Nominal GDP) Fixed-Window Approach

\section{Dependent variable:}

Average real GDP per capita growth over $T_{6}$ to $T_{10}$

\begin{tabular}{|c|c|c|c|c|c|c|c|c|c|c|}
\hline & reg1 & reg2 & reg3 & reg4 & reg5 & reg6 & reg7 & reg8 & reg9 & reg10 \\
\hline $\begin{array}{l}\text { Change in Debt/GDP ratio }\left(T_{0}-T_{5}\right) \\
\text { (minus sign = "deleveraging") }\end{array}$ & $\begin{array}{r}-0.019 \\
(0.012)\end{array}$ & $\begin{array}{r}-0.042^{* \star *} \\
(0.013)\end{array}$ & $\begin{array}{r}-0.036^{* * *} \\
(0.012)\end{array}$ & $\begin{array}{r}-0.036^{* * *} \\
(0.013)\end{array}$ & $\begin{array}{r}-0.037^{* * *} \\
(0.013)\end{array}$ & $\begin{array}{r}-0.038^{* * *} \\
(0.014)\end{array}$ & $\begin{array}{r}-0.039^{* * *} \\
(0.015)\end{array}$ & $\begin{array}{r}-0.039^{* * *} \\
(0.014)\end{array}$ & $\begin{array}{l}-0.030^{*} \\
(0.017)\end{array}$ & $\begin{array}{l}-0.030^{*} \\
(0.017)\end{array}$ \\
\hline Output growth $\left(T_{0}-T_{5}\right)$ & & $\begin{array}{r}0.539^{* * *} \\
(0.113)\end{array}$ & $\begin{array}{r}0.540^{* * *} \\
(0.118)\end{array}$ & $\begin{array}{r}0.544^{* * *} \\
(0.117)\end{array}$ & $\begin{array}{r}0.540^{* * *} \\
(0.121)\end{array}$ & $\begin{array}{r}0.594^{* * *} \\
(0.113)\end{array}$ & $\begin{array}{r}0.588^{* * *} \\
(0.117)\end{array}$ & $\begin{array}{r}0.586^{\star * *} \\
(0.127)\end{array}$ & $\begin{array}{r}0.618^{* * *} \\
(0.100)\end{array}$ & $\begin{array}{r}0.621^{* * *} \\
(0.106)\end{array}$ \\
\hline $\begin{array}{l}\text { REER appreciation }\left(\mathrm{T}_{0}-\mathrm{T}_{5}\right) \\
\quad \text { (minus sign = "appreciation") }\end{array}$ & & & $\begin{array}{l}-0.034^{*} \\
(0.018)\end{array}$ & $\begin{array}{l}-0.034^{*} \\
(0.018)\end{array}$ & $\begin{array}{r}-0.033 \\
(0.021)\end{array}$ & $\begin{array}{r}-0.021 \\
(0.019)\end{array}$ & $\begin{array}{r}-0.019 \\
(0.021)\end{array}$ & $\begin{array}{r}-0.019 \\
(0.021)\end{array}$ & $\begin{array}{l}-0.032^{*} \\
(0.018)\end{array}$ & $\begin{array}{l}-0.032^{*} \\
(0.018)\end{array}$ \\
\hline GDP per capita relative to US at $T_{0}$ & & & & $\begin{array}{l}-0.595 \\
(0.542)\end{array}$ & $\begin{array}{r}-0.671 \\
(0.623)\end{array}$ & $\begin{array}{r}-0.248 \\
(0.544)\end{array}$ & $\begin{array}{r}-0.146 \\
(0.649)\end{array}$ & $\begin{array}{r}-0.159 \\
(0.665)\end{array}$ & $\begin{array}{l}-0.012 \\
(0.622)\end{array}$ & $\begin{array}{r}0.008 \\
(0.639)\end{array}$ \\
\hline Private Debt/GDP at $T_{0}$ & & & & & $\begin{array}{r}-0.001 \\
(0.006)\end{array}$ & & $\begin{array}{r}-0.002 \\
(0.006)\end{array}$ & $\begin{array}{l}-0.002 \\
(0.006)\end{array}$ & $\begin{array}{r}0.000 \\
(0.004)\end{array}$ & $\begin{array}{r}0.000 \\
(0.005)\end{array}$ \\
\hline Gov't Debt/GDP at $T_{0}$ & & & & & & $\begin{array}{l}-0.005 \\
(0.008)\end{array}$ & $\begin{array}{r}-0.004 \\
(0.008)\end{array}$ & $\begin{array}{r}-0.004 \\
(0.009)\end{array}$ & $\begin{array}{r}-0.005 \\
(0.008)\end{array}$ & $\begin{array}{l}-0.005 \\
(0.009)\end{array}$ \\
\hline $\begin{array}{l}\text { Avg change in fiscal balance }\left(T_{0}-T_{5}\right) \\
\quad \text { (minus sign = "expansion") }\end{array}$ & & & & & & & & $\begin{array}{l}-0.031 \\
(0.399)\end{array}$ & & $\begin{array}{r}0.031 \\
(0.391)\end{array}$ \\
\hline $\begin{array}{r}\text { Change in policy rate }\left(T_{5}-T_{0}\right) \\
\text { (minus sign = "loosening") }\end{array}$ & & & & & & & & & $\begin{array}{r}-0.116^{* * *} \\
(0.044)\end{array}$ & $\begin{array}{r}-0.116^{* * *} \\
(0.045)\end{array}$ \\
\hline Number of observations & 71 & 71 & 71 & 71 & 71 & 67 & 67 & 67 & 67 & 67 \\
\hline $\begin{array}{l}\text { Adjusted } R^{2} \\
\text { note: }{ }^{* * *} p<0.01,{ }^{* *} p<0.05,{ }^{*} p<0.1 \\
\text { Figures in parantheses are standard e } \\
\text { The symbols }{ }^{* * *},{ }^{* *},{ }^{*} \text { denote significe }\end{array}$ & 0.009 & 0.317 & 0.347 & 0.338 & 0.328 & 0.394 & 0.386 & 0.376 & 0.455 & 0.445 \\
\hline
\end{tabular}


Table 2. Impact of Deleveraging on Future Output Growth 5 years Post Deleveraging - (Nominal Private Debt/Nominal GDP) Episode-Based Approach

\section{Dependent variable:}

Average real GDP per capita growth over 5 years post deleveraging

\begin{tabular}{|c|c|c|c|c|c|c|c|c|c|c|c|}
\hline & Reg 1 & Reg 2 & Reg 3 & Reg 4 & Reg 5 & Reg 6 & Reg 7 & Reg 8 & Reg 9 & Reg 10 & Reg 11 \\
\hline Change in Debt/GDP ratio per yr during Deleveraging & $-0.200^{* *}$ & $-0.201^{* *}$ & $-0.146^{*}$ & $-0.144^{*}$ & $-0.128^{*}$ & $-0.162^{*}$ & -0.126 & $-0.240^{\star *}$ & $-0.186^{*}$ & $-0.177^{*}$ & -0.152 \\
\hline ( minus sign = "deleveraging") & $(0.096)$ & $(0.094)$ & $(0.078)$ & $(0.075)$ & $(0.076)$ & $(0.088)$ & $(0.080)$ & $(0.094)$ & $(0.096)$ & $(0.101)$ & $(0.103)$ \\
\hline Length of deleveraging (yrs) & & $-0.179^{* *}$ & -0.076 & -0.099 & -0.113 & -0.109 & -0.092 & -0.076 & -0.051 & -0.076 & -0.086 \\
\hline (positive sign $=$ longer deleveraging $)$ & & $(0.084)$ & $(0.071)$ & $(0.070)$ & $(0.070)$ & $(0.070)$ & $(0.065)$ & $(0.064)$ & $(0.063)$ & $(0.067)$ & $(0.067)$ \\
\hline \multirow[t]{2}{*}{ Output growth during deleveraging } & & & $0.443^{\star * \star}$ & $0.381^{* * *}$ & $0.339^{* * *}$ & $0.346^{* * *}$ & $0.402^{* * *}$ & $0.445^{* * *}$ & $0.430^{* * *}$ & $0.463^{* * *}$ & $0.447^{* * *}$ \\
\hline & & & $(0.077)$ & $(0.079)$ & $(0.085)$ & $(0.085)$ & $(0.081)$ & $(0.081)$ & $(0.083)$ & $(0.084)$ & $(0.085)$ \\
\hline REER appreciation during deleveraging & & & & $-0.126^{\star *}$ & $-0.107^{*}$ & $-0.099^{*}$ & $-0.102^{*}$ & -0.063 & -0.021 & -0.087 & -0.063 \\
\hline (minus sign = "appreciation") & & & & $(0.054)$ & $(0.055)$ & $(0.057)$ & $(0.056)$ & $(0.057)$ & $(0.059)$ & $(0.068)$ & $(0.070)$ \\
\hline \multirow{2}{*}{ Real GDP per capita relative to US at $T_{0}$} & & & & & -0.649 & -0.404 & -0.197 & 0.569 & 0.619 & 0.703 & 0.600 \\
\hline & & & & & $(0.480)$ & $(0.579)$ & $(0.467)$ & $(0.576)$ & $(0.571)$ & $(0.595)$ & $(0.597)$ \\
\hline \multirow[t]{2}{*}{ Private Debt/GDP at $T_{0}$} & & & & & & -0.004 & & $-0.011^{\star *}$ & $-0.010^{*}$ & $-0.010^{*}$ & $-0.009^{*}$ \\
\hline & & & & & & $(0.005)$ & & $(0.005)$ & $(0.005)$ & $(0.005)$ & $(0.005)$ \\
\hline \multirow[t]{2}{*}{ Govt Debt/GDP at $T_{0}$} & & & & & & & -0.006 & -0.003 & -0.011 & -0.012 & -0.013 \\
\hline & & & & & & & $(0.007)$ & $(0.007)$ & $(0.007)$ & $(0.008)$ & $(0.008)$ \\
\hline Avg annual change in fiscal balance $\left(T_{0}-T_{5}\right)$ & & & & & & & & & -0.183 & & -0.315 \\
\hline (minus sign = "expansion") & & & & & & & & & $(0.199)$ & & $(0.253)$ \\
\hline \multirow{2}{*}{$\begin{array}{c}\text { Change in policy rate }\left(T_{0}-T_{5}\right) \\
\text { (minus sign = "loosening") }\end{array}$} & & & & & & & & & & $-0.050^{*}$ & $-0.049^{*}$ \\
\hline & & & & & & & & & & $(0.027)$ & $(0.027)$ \\
\hline Number of observations & 71 & 71 & 71 & 71 & 71 & 71 & 67 & 67 & 65 & 56 & 56 \\
\hline Adjusted $\mathrm{R}^{2}$ & 0.046 & 0.093 & 0.385 & 0.423 & 0.431 & 0.427 & 0.487 & 0.516 & 0.504 & 0.530 & 0.536 \\
\hline
\end{tabular}


Table 3. Impact of Deleveraging on Future Output Growth - (Interaction between intensity and duration)

\section{Dependent variable:}

Avg. real GDP per capita growth post deleveraging

\begin{tabular}{llllllllllll}
$\operatorname{Reg} 1$ & $\operatorname{Reg} 2$ & $\operatorname{Reg} 3$ & $\operatorname{Reg} 4$ & $\operatorname{Reg} 5$ & $\operatorname{Reg} 6$ & $\operatorname{Reg} 7$ & $\operatorname{Reg} 8$ & $\operatorname{Reg} 9$ & $\operatorname{Reg} 10$ & $\operatorname{Reg} 11$ & $\operatorname{Reg} 12$ \\
\hline
\end{tabular} Change in Debt/GDP ratio per year relative to average during deleveraging

(negative sign = "deleveraging")

$-0.200^{* *}$

$-0.201^{* *}-0.21$

$-0.216^{* *}$

$0.142^{*}$

$-0.150 *-0.2$

$0.220^{* *}-0.279^{* * *}$

$\begin{array}{lllllllllll}-0.179^{\star *} & -0.166^{\star *} & -0.064 & -0.086 & -0.100 & -0.100 & -0.087 & -0.078 & -0.056 & -0.078 & -0.088\end{array}$

Length of deleveraging relative to average (yrs)

(positive sign $=$ longer than average)

Interaction: Deleveraging intensity \& duration relative to avg

(positive $=$ deleveraging above avg of $3.6 \%$ of GDP \&

duration below avg of $4.7 \mathrm{yrs}$ )

Output growth during deleveraging

REER appreciation during deleveraging

( minus sign = "appreciation")

$\begin{array}{rr}-0.179^{* *} & -0.166^{* *} \\ (0.084) & (0.083)\end{array}$

-0.064
$(0.070)$

-0.086
$0.069)$

(0.069)

(0.070)

(0.062)

$(0.062)$

(0.062)

$\begin{array}{llllllllll}0.054 & 0.050^{*} & 0.049^{*} & 0.048^{*} & 0.046 & 0.078^{* *} & 0.062^{*} & 0.046 & 0.047 & 0.045\end{array}$

(0.035)

$(0.029) \quad(0.028)$

$0.028)$

(0.031)

$(0.033)$

(0.033)

$(0.034) \quad(0.034)$

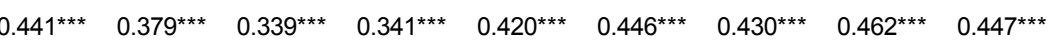

$\begin{array}{lllllllll}(0.076) & (0.078) & (0.083) & (0.084) & (0.078) & (0.080) & (0.082) & (0.084) & (0.084)\end{array}$

$\begin{array}{llllllll}-0.125^{* *} & -0.106^{*} & -0.104^{*} & -0.069 & -0.049 & -0.015 & -0.088 & -0.066\end{array}$

Real GDP per capita relative to US at $\mathrm{T}_{0}$

$\begin{array}{llllllll}(0.053) & (0.055) & (0.056) & (0.055) & (0.056) & (0.059) & (0.067) & (0.070)\end{array}$

Private Debt/GDP at $\mathrm{T}_{0}$

$\begin{array}{lllllll}-0.622 & -0.561 & -0.157 & 0.357 & 0.446 & 0.582 & 0.487\end{array}$

$\begin{array}{lllllll}(0.473) & (0.581) & (0.448) & (0.575) & (0.580) & (0.596) & (0.598)\end{array}$

$\begin{array}{lllll}-0.001 & -0.007 & -0.007 & -0.008 & -0.007\end{array}$

Gov't Debt/GDP at $T_{0}$

$\begin{array}{lllll}(0.005) & (0.005) & (0.005) & (0.006) & (0.006)\end{array}$

Change in fiscal balance per year during deleveraging

(minus sign = "expansion")

$\begin{array}{lllll}-0.006 & -0.004 & -0.011 & -0.012 & -0.013\end{array}$

$\begin{array}{lllll}(0.007) & (0.007) & (0.007) & (0.008) & (0.008)\end{array}$

Change in policy rate during deleveraging

(minus sign = "loosening")

Number of observations

更

Figures in parantheses are standard errors.

The symbols ${ }^{* * *},{ }^{* *},{ }^{*}$ denote significance at 1,5 and 10 percent, respectively. 
Table 4. Impact of Deleveraging on Future Output Growth - (Cyclical deviation in Debt/NGDP)

Dependent variable:

Avg. real GDP per capita growth 5 yrs post deleveraging

\begin{tabular}{|c|c|c|c|c|c|c|c|c|c|c|c|}
\hline & Reg 1 & $\operatorname{Reg} 2$ & Reg 3 & Reg 4 & Reg 5 & Reg 6 & $\operatorname{Reg} 7$ & Reg 8 & $\operatorname{Reg} 9$ & Reg 10 & Reg 11 \\
\hline \multirow{2}{*}{$\begin{array}{l}\text { Change in cyclical PV/GDP ratio per year during deleveraging } \\
\text { (minus sign = "deleveraging") }\end{array}$} & -0.110 & -0.127 & -0.093 & -0.076 & -0.057 & -0.128 & -0.081 & $-0.182^{* *}$ & $-0.188^{* *}$ & $-0.198^{* *}$ & $-0.189^{* *}$ \\
\hline & $(0.092)$ & $(0.091)$ & $(0.070)$ & $(0.071)$ & $(0.069)$ & $(0.083)$ & $(0.070)$ & $(0.082)$ & $(0.078)$ & $(0.084)$ & $(0.085)$ \\
\hline \multirow{2}{*}{$\begin{array}{l}\text { Length of deleveraging }(\mathrm{yrs}) \\
\quad(\text { positive sign }=\text { longer deleveraging) }\end{array}$} & & $-0.203^{* *}$ & $-0.116^{*}$ & $-0.127^{*}$ & $-0.122^{*}$ & $-0.118^{*}$ & $-0.120^{* *}$ & $-0.114^{*}$ & $-0.098^{*}$ & -0.076 & -0.091 \\
\hline & & $(0.086)$ & $(0.067)$ & $(0.067)$ & $(0.065)$ & $(0.064)$ & $(0.061)$ & $(0.060)$ & $(0.058)$ & $(0.069)$ & $(0.071)$ \\
\hline \multirow[t]{2}{*}{ Output growth during deleveraging } & & & $0.551^{* * *}$ & $0.554^{* * *}$ & $0.491^{* * *}$ & $0.501^{* * *}$ & $0.531^{* * *}$ & $0.551^{* * *}$ & $0.571^{\star \star *}$ & $0.559^{* * *}$ & $0.582^{* * *}$ \\
\hline & & & $(0.063)$ & $(0.063)$ & $(0.065)$ & $(0.065)$ & $(0.063)$ & $(0.062)$ & $(0.064)$ & $(0.067)$ & $(0.071)$ \\
\hline \multirow{2}{*}{$\begin{array}{l}\text { REER appreciation during deleveraging } \\
\text { (minus sign = "appreciation") }\end{array}$} & & & & -0.075 & -0.056 & -0.049 & -0.037 & -0.022 & $-0.120^{*}$ & -0.074 & -0.101 \\
\hline & & & & $(0.057)$ & $(0.056)$ & $(0.056)$ & $(0.057)$ & $(0.057)$ & $(0.064)$ & $(0.067)$ & $(0.074)$ \\
\hline \multirow{2}{*}{ Real GDP per capita relative to US at $T_{0}$} & & & & & $-1.129^{* * *}$ & -0.674 & $-0.903^{* *}$ & -0.238 & 0.114 & 0.094 & 0.188 \\
\hline & & & & & $(0.404)$ & $(0.500)$ & $(0.391)$ & $(0.486)$ & $(0.470)$ & $(0.494)$ & $(0.505)$ \\
\hline \multirow[t]{2}{*}{ Private Debt/GDP at $T_{0}$} & & & & & & -0.007 & & $-0.010^{* *}$ & $-0.011^{* * *}$ & $-0.011^{* *}$ & $-0.011^{* *}$ \\
\hline & & & & & & $(0.005)$ & & $(0.005)$ & $(0.004)$ & $(0.005)$ & $(0.005)$ \\
\hline \multirow[t]{2}{*}{ Gov't Debt/GDP at $T_{0}$} & & & & & & & -0.006 & -0.005 & -0.003 & -0.004 & -0.003 \\
\hline & & & & & & & $(0.006)$ & $(0.006)$ & $(0.005)$ & $(0.006)$ & $(0.006)$ \\
\hline \multirow{2}{*}{$\begin{array}{l}\text { Change in fiscal balance per year during deleveraging } \\
\text { (minus sign = "expansion") }\end{array}$} & & & & & & & & & 0.135 & & 0.190 \\
\hline & & & & & & & & & $(0.181)$ & & $(0.209)$ \\
\hline \multirow{2}{*}{$\begin{array}{l}\text { Change in policy rate during deleveraging } \\
\text { (minus sign = "loosening") }\end{array}$} & & & & & & & & & & 0.004 & -0.003 \\
\hline & & & & & & & & & & $(0.025)$ & $(0.026)$ \\
\hline Number of observations & 110 & 110 & 110 & 110 & 110 & 110 & 105 & 105 & 102 & 89 & 89 \\
\hline Adjusted R2 & 0.004 & 0.045 & 0.438 & 0.442 & 0.476 & 0.482 & 0.541 & 0.559 & 0.569 & 0.550 & 0.549 \\
\hline
\end{tabular}

Figures in parantheses are standard errors.

The symbols ${ }^{* * *},{ }^{* *},{ }^{*}$ denote significance at 1,5 and 10 percent, respectively. 
Table 5. Impact of Deleveraging on Future Investment Growth - (Corporate Debt/Profits)

\section{Dependent variable:}

Avg. real investment per capita growth for 3 years post deleveraging

\begin{tabular}{|c|c|c|c|c|c|c|c|c|c|c|c|}
\hline & Reg 1 & Reg 2 & Reg 3 & Reg 4 & Reg 5 & Reg 6 & Reg 7 & Reg 8 & Reg 9 & Reg 10 & Reg 11 \\
\hline $\begin{array}{l}\text { Change in NFC debt/Profit ratio per year during deleveraging } \\
\text { (minus sign = "deleveraging") }\end{array}$ & $\begin{array}{r}0.005 \\
(0.007)\end{array}$ & $\begin{array}{r}0.004 \\
(0.007)\end{array}$ & $\begin{array}{r}0.002 \\
(0.007)\end{array}$ & $\begin{array}{r}0.002 \\
(0.007)\end{array}$ & $\begin{array}{r}0.006 \\
(0.008)\end{array}$ & $\begin{array}{r}0.003 \\
(0.020)\end{array}$ & $\begin{array}{r}0.008 \\
(0.008)\end{array}$ & $\begin{array}{r}0.012 \\
(0.022)\end{array}$ & $\begin{array}{r}0.014 \\
(0.023)\end{array}$ & $\begin{array}{r}0.017 \\
(0.022)\end{array}$ & $\begin{array}{r}0.020 \\
(0.024)\end{array}$ \\
\hline $\begin{array}{l}\text { Length of deleveraging (yrs) } \\
\qquad \text { (positive sign = longer deleveraging) }\end{array}$ & & $\begin{array}{l}-0.415^{\star} \\
(0.213)\end{array}$ & $\begin{array}{r}-0.465^{\star *} \\
(0.230)\end{array}$ & $\begin{array}{r}-0.520^{* *} \\
(0.240)\end{array}$ & $\begin{array}{r}-0.371 \\
(0.282)\end{array}$ & $\begin{array}{r}-0.338 \\
(0.348)\end{array}$ & $\begin{array}{r}-0.311 \\
(0.287)\end{array}$ & $\begin{array}{r}-0.349 \\
(0.347)\end{array}$ & $\begin{array}{r}-0.425 \\
(0.457)\end{array}$ & $\begin{array}{r}-0.556 \\
(0.390)\end{array}$ & $\begin{array}{r}-0.665 \\
(0.502)\end{array}$ \\
\hline Real investment growth during deleveraging & & & $\begin{array}{c}-0.082 \\
(0.133)\end{array}$ & $\begin{array}{r}-0.050 \\
(0.139)\end{array}$ & $\begin{array}{r}-0.071 \\
(0.140)\end{array}$ & $\begin{array}{c}-0.074 \\
(0.144)\end{array}$ & $\begin{array}{r}-0.083 \\
(0.140)\end{array}$ & $\begin{array}{r}-0.080 \\
(0.144)\end{array}$ & $\begin{array}{c}-0.105 \\
(0.174)\end{array}$ & $\begin{array}{c}-0.092 \\
(0.149)\end{array}$ & $\begin{array}{c}-0.127 \\
(0.181)\end{array}$ \\
\hline $\begin{array}{l}\text { REER appreciation during deleveraging } \\
\text { (minus sign = "appreciation") }\end{array}$ & & & & $\begin{array}{l}-0.188 \\
(0.216)\end{array}$ & $\begin{array}{l}-0.112 \\
(0.229)\end{array}$ & $\begin{array}{r}-0.108 \\
(0.234)\end{array}$ & $\begin{array}{l}-0.072 \\
(0.231)\end{array}$ & $\begin{array}{r}-0.075 \\
(0.236)\end{array}$ & $\begin{array}{r}-0.084 \\
(0.243)\end{array}$ & $\begin{array}{r}0.023 \\
(0.256)\end{array}$ & $\begin{array}{r}0.013 \\
(0.262)\end{array}$ \\
\hline Real GDP per capita relative to US at $T_{0}$ & & & & & $\begin{array}{r}-3.396 \\
(3.387)\end{array}$ & $\begin{array}{r}-3.296 \\
(3.501)\end{array}$ & $\begin{array}{r}-4.003 \\
(3.425)\end{array}$ & $\begin{array}{r}-4.175 \\
(3.591)\end{array}$ & $\begin{array}{r}-4.169 \\
(3.660)\end{array}$ & $\begin{array}{r}-5.230 \\
(3.827)\end{array}$ & $\begin{array}{r}-5.263 \\
(3.906)\end{array}$ \\
\hline Total NFC Debt/Profit at $T_{0}$ & & & & & & $\begin{array}{r}-0.000 \\
(0.002)\end{array}$ & & $\begin{array}{r}0.000 \\
(0.002)\end{array}$ & $\begin{array}{r}0.001 \\
(0.003)\end{array}$ & $\begin{array}{r}0.002 \\
(0.003)\end{array}$ & $\begin{array}{r}0.002 \\
(0.003)\end{array}$ \\
\hline Govt Debt/GDP at $T_{0}$ & & & & & & & $\begin{array}{r}-0.025 \\
(0.023)\end{array}$ & $\begin{array}{r}-0.027 \\
(0.025)\end{array}$ & $\begin{array}{c}-0.027 \\
(0.026)\end{array}$ & $\begin{array}{r}-0.018 \\
(0.028)\end{array}$ & $\begin{array}{r}-0.018 \\
(0.028)\end{array}$ \\
\hline $\begin{array}{l}\text { Change in fiscal balance per year during deleveraging } \\
\text { (minus sign = "expansion") }\end{array}$ & & & & & & & & & $\begin{array}{l}-0.222 \\
(0.846)\end{array}$ & & $\begin{array}{r}-0.308 \\
(0.869)\end{array}$ \\
\hline $\begin{array}{l}\text { Change in policy rate during deleveraging } \\
\text { (minus sign = "loosening") }\end{array}$ & & & & & & & & & & $\begin{array}{r}-0.456 \\
(0.377)\end{array}$ & $\begin{array}{l}-0.468 \\
(0.386)\end{array}$ \\
\hline Number of observations & 33 & 33 & 33 & 33 & 33 & 33 & 33 & 33 & 33 & 31 & 31 \\
\hline Adjusted R2 & -0.013 & 0.070 & 0.050 & 0.043 & 0.043 & 0.007 & 0.048 & 0.011 & -0.027 & 0.022 & -0.019 \\
\hline
\end{tabular}




\section{APPENDIX 3: TWO-STEP APPROACH TO ISOLATE EXTREME EXOGENOUS DELEVERAGING SHOCKS}

This appendix describes an alternative empirical methodology to assess the impact of private sector deleveraging on real (per capita) output in a group of 36 emerging and advanced economies over the period 1960 and 2013.

\section{A. Exogenous episodes of private sector deleveraging}

To address reverse causality from growth to deleveraging, the first step consists of estimating private sector deleveraging episodes using various explanatory variables:

$\Delta P S D_{i, t}=\alpha_{i+} \tau_{i, t}+\sum_{j=1}^{l} \beta_{j} \Delta y_{i, t-j}+\sum_{j=1}^{l} \gamma_{j} x_{i, t-j}+\varepsilon i, t$

$(1)$,

where PSD is a change in private sector credit-to-GDP, household credit-to-GDI, or corporate debt-toprofit ratio; $\beta_{j}$ captures the impact of contemporaneous and lagged output growth; and $x$ is a vector of control variables, including changes in monetary policy interest rates, trade openness, and a banking crisis dummy. The residuals $-\varepsilon_{i, t}$-are then used to construct extreme exogenous events of private sector deleveraging $\left(D_{i, t}\right)$ as

$\left\{\begin{array}{l}D_{i, t}=1 \quad \text { if } \varepsilon_{i, t}<a \\ D_{i, t}=0, \quad \text { otherwise }\end{array}\right.$

where $a$ corresponds to the value of the $5^{\text {th }}$ percentile of the distribution. The number of indentified exogenous deleveraging episodes is listed in the table below.

Table 1: Number of deleveraging episodes (1965-2012)

\begin{tabular}{l|c|c}
\hline & AEs & EMs \\
\hline Credit-to-GDP & 29 & 23 \\
Corporate debt-to-Profit & 16 & 1 \\
Household debt-to-GDI & 16 & 4
\end{tabular}

\section{B. Impulse response functions of output}

The second step consists of deriving the impulse response functions of real (per capita) output to extreme exogenous deleveraging events using local projections (Jorda, 2005) by estimating a set of $\mathrm{k}$ (with $\mathrm{k}=1, \ldots, 5$ ) independent equations:

$y_{i, t+k}-y_{i, t}=\alpha_{i}^{k}+\sum_{j=1}^{l} \beta_{j}^{k} \Delta y_{i, t-j}+\sum_{j=1}^{l} \gamma_{j}^{k} \Delta x_{i, t-j}+\varphi_{k} D_{i, t}+\varepsilon_{i, t}^{k}$

(2),

where $y_{i, t}$ is the log of real GDP per capita, $\varphi_{k}$ captures the impact of deleveraging episodes on output, $\beta_{j}^{k}$ - the effect of persistence in output growth; and $\Delta x_{i, t-j}$ is a set of variables influencing output in the short and medium term. The results (Figure 1-6) obtained with this two-step approach confirm that a 
sharp reduction in the private sector debt has a significant and persistent effect on output. In particular, the occurrence of an exogenous deleveraging episode increases real output by 0.6 percent in the short term, with the 5-year cumulative effect of about 2.8 percent. The effect seems to be driven by the corporate sector deleveraging rather than the household sector. The impact on real output is also larger about 3.5 percent after 5 year-when private sector deleveraging is associated with bank restructuring, especially in advanced economies.
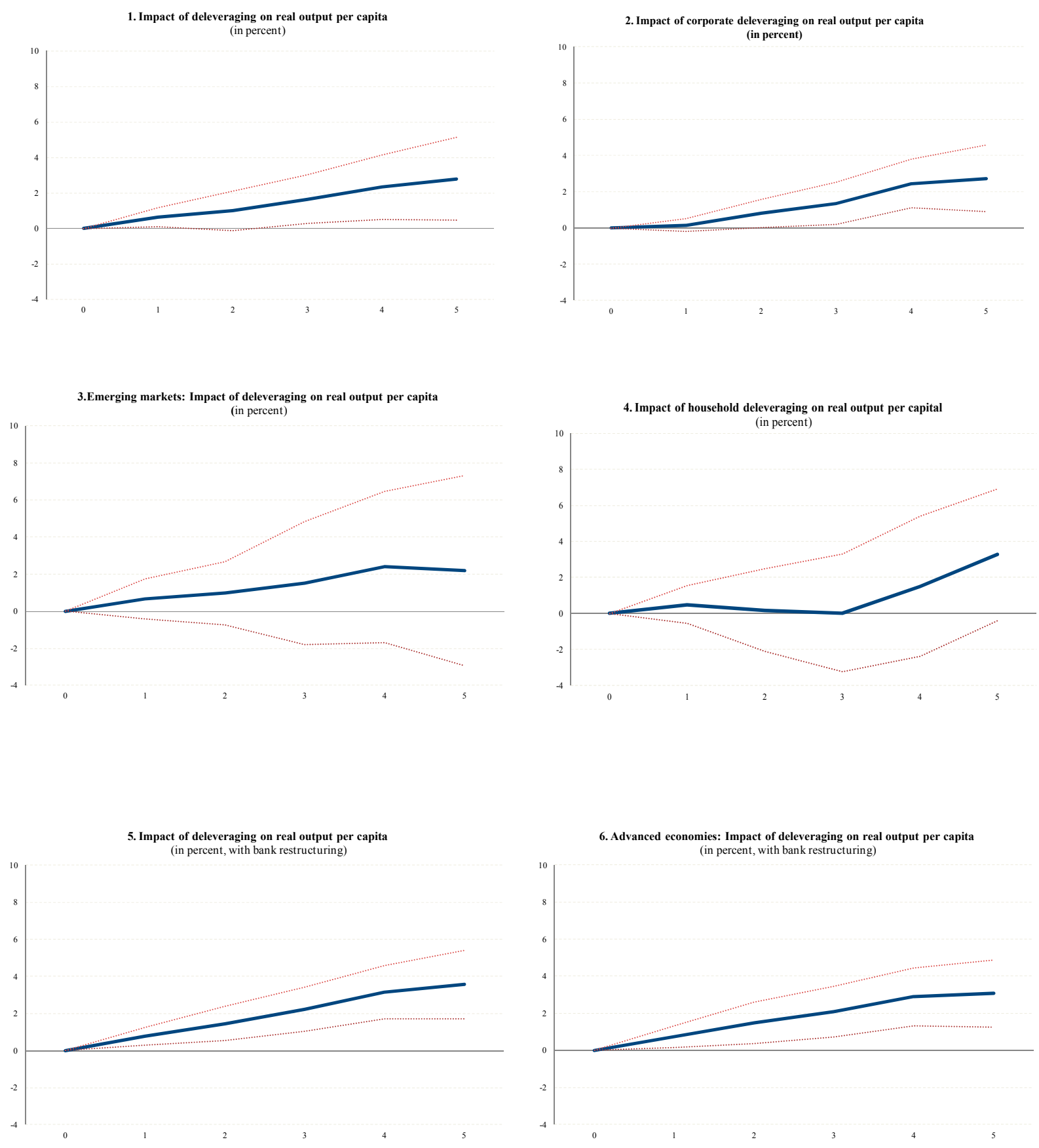